Max-Planck-Institut für demografische Forschung

Max Planck Institute for Demographic Research

Konrad-Zuse-Strasse 1 - D-18057 Rostock · GERMANY

Tel +49 (0) 3812081 - 0; Fax +49 (0) 3812081 - 202;

http://www.demogr.mpg.de

MPIDR WORKING PAPER WP 2008-027

NOVEMBER 2008

The impact of a migration-caused

selection effect on regional

mortality differences in Italy and

Germany

Marc Luy

Graziella Caselli

This working paper has been approved for release by: Gabriele Doblhammer-Reiter

(doblhammer@demogr.mpg.de)

Co-Director of the Rostock Center for the Study of Demographic Change.

(C) Copyright is held by the authors.

Working papers of the Max Planck Institute for Demographic Research receive only limited review. Views or opinions expressed in working papers are attributable to the authors and do not necessarily reflect those of the Institute. 


\title{
The impact of a migration-caused selection effect on regional mortality differences in Italy and Germany ${ }^{1}$
}

\author{
Marc Luy* and Graziella Caselli** \\ * Federal Institute for Population Research, Wiesbaden, Germany \\ ** Department of Demography, University of Rome "La Sapienza", Italy
}

Paper presented at the PAA 2004 Annual Meeting, Boston, April 1-3

\section{Introduction and aim of the study}

Regional mortality differences are known for a lot of countries but are usually examined solely for single nations. One of the very few exceptions is the comparative description of regional mortality differences in several countries by Caselli and Vallin (2002). The aim of this research project is to do a comparative analysis of regional mortality differences in Germany and Italy that exceeds the level of pure description and analyses also the causes of this differences on the macro as well as on the micro level. In both countries survival conditions are not uniquely distributed over the whole national areas. However, a more detailed analysis of regional mortality was done solely in Italy (Caselli and Egidi 1980, Caselli and Reale 1999,

\footnotetext{
${ }^{1}$ This paper is part of the Research Training Network (RTN)-project "Regional mortality differences in Italy and Germany - Analysis of similarities and differences regarding developments and responsible factors" (RTN DEMOG, financed by the EU). The authors cordially thank Hansjörg Bucher from BBR (Bundesamt für Bauwesen und Raumordnung in Bonn, Germany) and Marco Marsili from ISTAT (Istituto Nazionale di Statistica in Rome, Italy) for providing the German and Italian data on district level to carry out this analysis.
} 
Caselli and Vallin 2002, Lipsi and Caselli 2002, Caselli et al. 2003). In Germany there are only a few works about mortality differences on the regional level (for "Bundesländer" or NUTS2) with simple descriptive results (Paul 1992; Sommer 1998, 2002; Bucher 2002). Mortality analysis on district level was exclusively done for several German regions (Wittwer-Backofen 1999, Gröner 2002, Mey 2002, Scholz and Thoelke 2002), but until today not in a complete national context. During the second half of the $20^{\text {th }}$ century regional mortality differences underwent different developments in the two countries. While in Italy they diminished, in Germany they remained at a remarkable level of 8.5 years in life expectancy at birth for men (compared to 4 years in Italy; see Tab. 1 and 2).

For analyzing regional mortality differences in Germany and Italy it is necessary to do a geographical differentiation of areas with homogeneous survival conditions. In Italy demographers distinguish between three main mortality regions: the North, the Center and the South (in some recent publications the North is further divided into North-East and North-West). This subdivision holds for historical mortality levels as well as for trends until today. For men it can be observed, that in the $2^{\text {nd }}$ half of the $20^{\text {th }}$ century the Northern and Central regions show the highest decrease in mortality while Center Italy improves only in some regions and deteriorates in others (Caselli et al. 2003). In the development of mortality reduction, the South lag behind considerably but among men (especially in the west coast areas) still shows the better survival conditions than the more developed North (Fig. 1). Consequently, despite the steeper mortality decline in the North, the North-South divide still persists. For women the geography of mortality is different from that of men. While the North shows similar disadvantages, in some parts of the South women's mortality is also higher than or closer to the national average as compared to men (Fig. 2). However, the amount of regional mortality differences is slightly smaller than among men (Tab. 2). Compared to this, in Germany the difference in the span of regional mortality levels between women and men is much higher (see Tab. 1). 
In Germany there are two completely different kinds of regional mortality differences overlapping each other. Most striking is the distinct East-West differentiation that is due to the special history of these two regions belonging to complete different political and social regimes for some decades during the last century (Höhn and Pollard 1991, Heinemann et al. 1996). Especially the developments in mortality following political Reunification in 1990 have recently attracted international attention and were analyzed in several studies (e. g. Eberstadt 1994; Nolte et al. 2000a, 2000b; Luy 2003). Compared to this it is almost unrecognized that especially in Western Germany also a clear North-South gradient in mortality is existing. Consequently, like in Italy, there are three regions of different mortality levels, namely the Center-South (in the following simply called "South") with the lowest mortality, followed by the North-West, and the North-East with the highest mortality (see Fig. 3 and 4). Contrariwise to the Italian situation, in Germany the North-South gradient is stable in time as well as between the sexes what becomes clear when recent and historical studies about regional mortality differences in Germany are analyzed (Lee 1984; Paul 1992; Sommer 1998, 2002; Bucher 2002; Luy 2004a). While the extent of this North-South divergence even increased in time, the East-West German mortality differences are decreasing continuously since reunification (Vaupel et al. 2003; Luy 2003, 2004b).

This paper is the first part of a bigger research project to analyze the causes of Italian and German regional mortality differences from various routes of both the macro and the micro perspective. It is obvious that regional mortality differences are generally caused by the combination of a huge number of different factors. The main goal of this study is to figure out those factors that are contributing to regional mortality differences similarly in both countries on the one side (and thus are thought to operate independent from cultural, economic, and social conditions) and those factors that can be assigned to special national conditions on the other side. In the course of this project we will examine the impact of the demographic structure (age- and cause-specific mortality as well as other demographic conditions and the social- 
demographic structure), the economic conditions of the regions (type of development, amount of unemployment, main types of occupation), the medical resources (availability/quality of medical as well as nursing care), and geographical factors (climatic differences, pollution, amount of industry, degree of urbanization) as factors operating on the macro level. On the micro level we will investigate the individual economic status (social status, occupation), the life circumstances (living arrangements, satisfaction with different parts of daily life connected with the specific area), the lifestyles (smoking, alcohol consumption, nutrition), and the impact of biological and genetic factors caused by heterogeneity of the population living in the various regions.

The last mentioned factor (like others as well) combines macro and micro level and is the topic of this first paper of this research project. We want to find out if beside the other named factors also migration affects regional mortality differences inside a country. It is known from several studies that migrants are healthier and thus show lower mortality than the immobile population what was described for various countries and ethnic groups for internal as well as for international migrants (e. g. Feinleib et al. 1981; Balarajan et al. 1984; Shai and Rosenwaike 1987; Tsugane et al. 1989; Nair et al. 1990; Valkonen et al. 1992; Kington et al. 1998; Razum et al. 1998a, 1998b; Singh and Siahpush 2001). ${ }^{2}$ Especially in terms of internal migration this phenomenon is explained by a special selection effect which may influence mortality and morbidity rates. This selective migration is expected to operate in two directions entailing the movement of a "select group" of healthy or unhealthy migrants (Shai and Rosenwaike 1987, McKay et al. 2003, Palloni and Arias 2003). The movement of healthier individuals is known as the so-called "healthy migrant phenomenon" (Sharma et al. 1990, Kington et al. 1998). On the other hand, it seems that sick individuals are involved in return mi-

\footnotetext{
${ }^{2}$ One of the few known exceptions are Scottish and Irish immigrants to England and Wales exhibiting higher mortality rates than the general population of England and Wales (Adelstein et al. 1986, Raftery et al. 1990, Wild and McKeigue 1997).
} 
gration, for example, to be nearer to family or care-giving institutions (Brimblecombe et al. 2000, Lanska and Peterson 1995, Razum et al. 1998b). The latter phenomenon is also known as "salmon bias" (Palloni and Arias 2003). ${ }^{3}$

Beside this, in the internal migration studies it is apparent that some migrant groups additionally benefit from a protective effect in terms of retention of a lower incidence of particular diseases, as was shown especially for Italy (Buiatti et al. 1985, Vigotti et al. 1988, Ceppi et al. 1995, Fascioli et al. 1995, Barbone et al. 1996) but also for other countries (Mancuso 1977, Coggon et al. 1990, Greenberg and Schneider 1995). ${ }^{4}$ Some of these effects may be due to genetic factors or the retention of certain dietary practices, since for instance associations have been found between breast cancer and body size, and daily intake of fat, in particular saturated fat, and alcohol consumption (Toniolo et al. 1989).

It is however unclear, if the healthy migrant phenomenon and the salmon bias are strong enough to contribute to survival conditions on the macro level and thus affect regional mortality differences like those of Italy and Germany. These two countries provide the ideal platform for examining if such a migration-caused selection effect on mortality exists since both contain areas of considerable emigration movements, namely the South of Italy and the North-Eastern part of Germany (the former GDR). Such a comparative analysis gains most interest from the fact that emigration from the South of Italy to the North and to the Center started in the 1960s with the largest movements until the 1970s (Golini 1974, Ascoli 1979),

\footnotetext{
${ }^{3}$ It should be stressed that the lower mortality of migrants is not only affected by physical condition but also by socioeconomic status (Wei et al. 1996, Harding and Maxwell 1998, Van Steenbergen et al. 1999). However, this doesn't hold for all ethnic migrant groups, what provides even more support to the "healthy migrant hypothesis" (Abraido-Lanza et al. 1983, King and Locke 1987).

${ }^{4}$ The complexity of the connection between migration and health can be seen from studies finding that not only place of birth but also place of death (Strachan et al. 1995) or place where men had lived for most of their adult lives (Elford et al. 1990) have an additional impact on mortality.
} 
while in Germany the emigration from the former GDR to West Germany started with the fall of the iron curtain and reunification around 1990 (Roloff 2000, Mai 2003b).

However, a direct estimate of the impact of such a migration-caused selection effect on mortality at a low regional level is almost impossible. Such a study would require both a migration matrix on the level of districts and the statistical separation of population data due to place of birth, place of residence, and age respective year of migration (for deaths as well as for the living population) what is not available in Italy as well as in Germany. Additionally, such a migration matrix would produce millions of data that then have to be combined with information about regional mortality. Consequently, a comparative analysis of a migrationcaused selection effect in Italy and Germany requires an indirect conception based on a powerful indicator. Our approach is based on the fact that migration (national as well as international) shows a clear and well-known age pattern (Preston et al. 2001). Emigration as well as immigration occurs mainly at young adult ages between 20 and 40 among women respective 20 and 50 among men, as can be seen in Fig. 5 for in- and out-migration to and from Germany in the year 2001. The biography of internal migration is almost identical (see Mai 2003a: 41). Consequently, if such an effect exists and contributes to regional mortality differences, there must be a relationship between the population age structure of the regions and their level of mortality. Since especially the above mentioned emigration areas in the two countries are clearly geographically restricted, a migration-caused selection effect on mortality should result in a negative statistical relationship between population age structure and level of mortality among the districts of Southern Italy and North-East Germany, i. e. the younger the population in the emigration areas is, the higher should be the overall level of mortality and vice versa. This hypothesis is based on the idea, that - if migrants are healthselected - a younger population loses relatively more healthy individuals by emigration than an older population as a consequence of the described age pattern of migrants. Furthermore, if such a migration-caused selection effect on mortality exists, in Germany the relationship be- 
tween population age structure and mortality should be concentrated on younger adult age groups, while in Italy the relationship should be stronger in older age groups since there the most intensive emigration movements occurred 20 to 30 years earlier.

South Italy and North-East Germany differ considerably regarding the main demographic parameters used in this study. In Germany the North-East is the region with the highest mortality among both sexes, while the South of Italy is only among women the area with higher mortality. South Italian men show tendentiously a mortality level slightly better than men in the developed North (Fig. 1). Although the absolute regional differences in life expectancy are considerably higher in Germany, most of the regions show a mortality level lying inside the standard deviation around the mean, as can be seen in the number of yellow areas in Figures 3 and 4. In contrary to that, especially among Italian men the regions are concentrated in the upper and the lower mortality levels (Fig. 1). Regarding the population age of this regions the differences between South Italy and North-East Germany are even bigger (Fig. 6 and 7; here the demographic age of the various regions is only shown for women since the results are almost identical for both sexes). ${ }^{5}$ While the South of Italy is the youngest of all Italian regions (blue colors in Figures 6 and 7), the North-Eastern German regions show a very heterogeneous age structure with a younger population in Sachsen, older populations in Mecklenburg-Vorpommern, Brandenburg, and Berlin as well as populations having a demographic age close to the German average (Sachsen-Anhalt and Thueringen). This preconditions form an ideal platform for testing the existence of a migration-caused selection effect on regional mortality differences. If the expected relationship between population age and mortality level exists in both countries, we can assume that this relationship is indeed due to a migration-caused selection and not due the specific combination of special demographic conditions that by chance could be observed in one of the two countries.

\footnotetext{
${ }^{5}$ According to the chosen measure for the demographic age a population is the older the more negative (smaller) the value for Billeter's $\mathrm{J}$ is. The measure itself is described in detail in the following section.
} 


\section{Data and methods}

The following analysis are based on sex-specific period life tables for the Italian and German districts of the three calendar years 1997 to 1999 . The complete Italian life tables were provided by ISTAT (L'Istituto Nazionale di Statistica in Rome, Italy). ${ }^{6}$ For Germany abridged life tables were calculated using age-specific population and death data on district level provided by the BBR (Bundesamt für Bauwesen und Raumordnung in Bonn, Germany). The life tables were calculated with Chiang's method for transforming age-specific death rates into probabilities of dying. ${ }^{7}$ Life expectancy at birth $\left(\mathrm{e}_{0}\right)$ is used as indicator for overall mortality. For age-specific analysis the chosen indicators are the probability of dying at ages 15 to $40\left({ }_{25} \mathrm{q}_{15}\right)$ and 50 to $75\left({ }_{25} \mathrm{q}_{50}\right)$ as well as the death rate at ages 75 and above $\left(\mathrm{M}_{75+}\right)$. This choice of indicators was necessary because German data for age-specific death numbers end with the age interval 70 to 75 and thus it is impossible to calculate probabilities of dying above age 75 for German districts.

An estimation of the demographic age of a population mainly depends on the chosen measure. Each measure for the demographic age of a population is necessarily a simplification of the complex age structure. This causes problems and restrictions comparable to using the parameter life expectancy or standardized mortality rates as indicators for overall mortality (Vaupel 2002, Luy 2004a). The decision about the used measure requires an orientation on the basic research question of the analysis. For our purpose the measure for the demographic age has to include the complete age range and should be calculated as easy as possible to provide clear and understandable results that can be interpreted unequivocally. Additionally, the measure should be sensitive and able to identify any differences between populations regarding the complete age composition.

\footnotetext{
${ }^{6}$ The complete series of life tables for the Italian districts can be downloaded from http://www.demo.istat.it

${ }^{7}$ Since the relationship between population age structure and mortality level is analyzed separately for Italy and Germany, the use of life tables calculated by different methods doesn't effect the reliability of the gained results.
} 
One measure that fulfils all mentioned demands was developed by the Swiss economist Billeter (1954). This measure is almost unknown in international research about demographic aging. In Germany it recently was rediscovered in several studies on demographic aging since it turned out to provide reliable results indicating clearly each difference between and changes in the age composition of populations (e. g. Dinkel 1989, Dinkel and Lebok 1997, Heigl 1998, Heigl and Mai 1999, Mai 2003b). Following a demographic intention, Billeter subdivided the population into three generations: the pre-reproductive population (including the ages 0 to 14 , thus the generation of children), the reproductive population (including the ages $15-49$, thus the generation of parents), and the post-reproductive population (including the ages 50 and above, thus the generation of grandparents). According to Billeter (1954) this subgroups characterize the actual and future potential of demographic development. The formula for Billeter's $\mathrm{J}$ is

$$
J=\frac{P_{0-14}-P_{50+}}{P_{15-49}} .
$$

According to Billeter's $\mathrm{J}$ demographic aging is defined by a relative increase of the population in post-reproductive ages as against the population in pre-reproductive ages. The measure can provide positive values (if $\mathrm{P}_{0-14}>\mathrm{P}_{50+}$ ) as well as negative values (if $\mathrm{P}_{0-14}<\mathrm{P}_{50^{+}}$), what is typical for today's populations of developed countries. The value zero represents a situation where pre- and post-reproductive age groups have the same size, but has no indication like a norm and thus has the same meaning as any other value. The positive or negative sign indicates the relative and absolute superiority of pre- respective post-reproductive age groups. Furthermore, the values +1 and -1 indicate that exactly half of the population live in the age groups $0-14$ respective $50+$. The most important meaning of $\mathrm{J}$ for its interpretation is that the smaller (in general the more negative) the value of $\mathrm{J}$ is, the older is the population and 
vice versa. In comparison to the usually used measures for demographic aging, the aging index $\left(\mathrm{P}_{65} / \mathrm{P}_{0-14}\right)$ and the share of people aged 60 and older $\left(\mathrm{P}_{60+} / \mathrm{P}\right)$ Billeter's $\mathrm{J}$ has the advantages of (a) including the whole age spectrum of a population, and (b) reacting extremely sensitive also on differences in the composition of age groups below 60. Finally, Billeter's J can be used in comparative static perspective (for comparing two populations at a given year) as well as in dynamic perspective (for analyzing the development of demographic aging in a given time-span). Because of its characteristics Billeter's $\mathrm{J}$ is the most suitable measure for the demographic age of a population in the needed context of this study.

For testing the existence of a migration-caused selection effect on regional mortality differences, the 103 Italian districts ("Province") are grouped into the regions North, Center, and South, the 440 German districts ("Kreise") into the regions North-West, North-East, and South (see Tab. 1 and 2). For each of these regions is examined if among the districts belonging to them a linear relationship is existing between the population age (measured by Billeter's J, indicating the relative size of younger respective older age groups) and the mentioned indicators for overall and age-specific mortality ( $e_{0}$ respective ${ }_{25} \mathrm{q}_{15},{ }_{25} \mathrm{q}_{50}$, and $\mathrm{M}_{75^{+}}$). For estimating the strength as well as the statistical significance of the correlation Pearson's $r$ is used. The analyses are done sex-specific and separately for Italy and Germany.

\section{Results}

In the presented results in Figures 8 to 23 we chose identical scales for Italy and Germany to allow also a comparison between the two countries. In the graphs the values for Billeter's $J$ are set on the X-axes (with the younger populations on the right side and the older populations on the left side), the indicators for the mortality level on the y-axes. An ItalianGerman comparison shows clearly the enormous differences between the two countries regarding their demographic conditions. While the mortality level is much more heterogeneous among German districts ( $\mathrm{e}_{0}$ ranges from 69.89 to 78.42 among German men and from 78.11 
to 83.96 among German women, while in Italy $\mathrm{e}_{0}$ ranges from 73.75 to 77.74 among men and from 79.99 to 83.64 among women; see Tab. 1 and 2), the Italian districts show much more differences in their demographic age (Billeter's $\mathrm{J}$ ranges from -0.11 to -0.73 among Italian men and from -0.28 to -1.08 among Italian women, while in Germany $\mathrm{J}$ ranges from -0.05 to -0.51 among men and from -0.18 to -0.85 among women; see Tab. 1 and 2). Tendentiously, the German population is younger than the Italian population, but life expectancy is higher in Italy. ${ }^{8}$ These results hold similarly for both sexes. The reason for the higher variability in life expectancy among German districts is mainly due to the high mortality in the North-Eastern regions (graphically represented as black squares in the figures for Germany). On the other side, the reason for the more heterogeneous distribution of population age among Italian districts is a consequence of bigger differences in regional fertility as compared to Germany, resulting in relatively old populations especially in the North and in the Center of Italy (represented by red rhombs and black squares in the figures for Italy).

The central research question of this study is if there exists a statistical relationship between population age and the mortality level among the North-Eastern German and South Italian districts. As can clearly be seen in Figures 8 and 9, among men the expected relationship can be found in both regions with high statistical significance. In Southern Italy the relationship is stronger with Pearson's $r$ being -0.552 , among North-Eastern German districts Pearson's $r$ equals -0.325 . According to the basic hypothesis, if this result is due to a migration-caused selection effect, then among North-Eastern German districts the relationship with Billeter's J should be stronger for mortality at younger adult ages, while among Southern Italian districts the relationship should be more pronounced at older ages. The following Fig-

\footnotetext{
${ }^{8}$ As already mentioned, a comparison of German and Italian life expectancy on district level is slightly distorted by the fact that the used methods for calculating the life tables are different, what finally could influence the absolute parameter values. Anyway, also according to the official life tables for the total populations Italy shows the higher expectancy.
} 
ures 10 to 15 show that exactly these relationships can be found with positive correlation between Billeter's $\mathbf{J}$ and the chosen indicators for age-specific mortality (meaning the younger the population the higher the mortality level). Among North-Eastern German districts the correlation with Billeter's $J$ is strongest with the probability of dying at ages 15 to $40{ }_{25} \mathrm{q}_{15}(\mathrm{r}=$ $0.256)$, followed by the probability of dying at ages 50 to $75{ }_{25} \mathrm{q}_{50}(\mathrm{r}=0.247)$ and the death rate at ages 75 and above $\mathrm{M}_{75^{+}}(\mathrm{r}=0.214)$. In all cases the correlation is statistically significant but slightly loses significance at the oldest age groups (see Tab. 3). Among Southern Italian districts no statistically significant correlation can be found between Billeter's $\mathrm{J}$ and ${ }_{25} \mathrm{q}_{15}$, but a strong statistically significant correlation between $J$ and ${ }_{25} q_{50}(r=0.464)$ and especially between $\mathrm{J}$ and $\mathrm{M}_{75^{+}}(\mathrm{r}=0.730$; see Tab. 3 and Figures 11, 13, and 15).

Among women similar results can be found for the Southern Italian regions (Figures $17,19,21$, and 23). Here the correlation between Billeter's $\mathrm{J}$ and life expectancy at birth $\mathrm{e}_{0}$ is strongest of all cases $(r=-0.708)$. Like among men, this relationship is not statistically significant at ages 15 to 40 , but highly statistically significant at ages 50 to $75(r=0.705)$ and at ages 75 and above $(r=0.654)$. Among women in the North-Eastern German districts no statistically significant correlation between population age and mortality level can be found. However, also here the sign of Pearson's $r$ corresponds with the basic hypotheses (see Figures $16,18,20$, and 22 as well as Tab. 3).

Finally we have a look at the correlation between population age and mortality level in the other German and Italian regions. Among German men in the North-Western districts exists a statistically significant positive correlation between Billeter's $J$ and life expectancy at birth $\mathrm{e}_{0}$, meaning the younger the population the lower overall mortality (or the higher life expectancy at birth). The correlation coefficients indicate that the reason for this finding is located in the mortality of the age groups 15 to 50 where Pearson's $r$ for the relationship between $\mathrm{J}$ and ${ }_{25} \mathrm{q}_{50}$ equals -0.292 with high statistically significance (Tab. 3). In the Southern districts exists no significant relationship between overall mortality and age of population, but 
there can be found a statistically significant correlation in opposite directions between $\mathrm{J}$ and ${ }_{25} \mathrm{q}_{50}$ respective $\mathrm{M}_{75^{+}}$(Figures 12 and 14). Almost the same relationships can be stated for women in the Southern and North-Western German districts (see Tab. 3).

Among Italian men in the districts in the North and in the Center as well as among Italian women in the Center there are no statistically significant relationships between population age and the level of mortality. This holds for both, overall mortality and age-specific mortality (see Tab. 3). Beside the findings regarding the South of Italy, only among women in the Northern districts a statistically significant correlation between Billeter's $\mathrm{J}$ and the mortality indicators can be found. Here the relationship is exactly contrary to the correlation in the South, meaning the younger the population the lower mortality (similar to the findings for the North-Western German districts). This result is mainly due to the mortality conditions in the younger and middle adult age groups, with $\mathrm{r}=0.431$ between $\mathrm{J}$ and $\mathrm{e}_{0}, \mathrm{r}=-0.404$ between $\mathrm{J}$ and ${ }_{25} \mathrm{q}_{15}$, and $\mathrm{r}=-0.414$ between $\mathrm{J}$ and ${ }_{25} \mathrm{q}_{50}$. The correlation between Billeter's $\mathrm{J}$ and the death rate at ages 75 and above $\mathrm{M}_{75^{+}}$is not statistically significant.

\section{Discussion}

The present study is the first step within a bigger research project to determine the macro and micro level factors that are responsible for regional mortality differences in Italy and Germany. In both countries there are three main mortality regions including a general mortality decrease from the North to the South. This similar North-South gradient in mortality exists despite complete different North-South diversities in economic and industrial conditions between the two countries. The decisive goal of this research project is to find out if these differences are caused by country specific factors, or if regional mortality differences are due to factors that work irrespective the specific economic and societal background. Thus the two main research questions are 
1. Which relationship can be found between various regional differences (in demographic structure, environmental conditions, specific individual risk factors, and so on) and regional mortality?

2. Do these relationships hold for both countries (and both sexes) or do the influences on and the relationships with mortality level differ between Italy and Germany?

It was the aim of this first research step to test the hypothesis that a migration-caused selection effect belongs to the group of factors contributing to and causing regional mortality differences. This effect is thought to be a consequence of individual decisions of migrating to and living in special areas, causing heterogeneous areas with healthier people in some regions on the one side and areas with more frail populations on the other side. Since a direct investigation of the impact of spatial population movements on mortality at low regional level is almost impossible we tried to find an indicator providing enough information to support or reject the basic hypothesis. The decisive idea of this study is that if a migration-caused selection effect exists, then there should be a statistical correlation between the age of a population and its mortality level resulting from the typical biography of migrations that are concentrated on the age groups 20 to 40 . Since the South of Italy and North-Eastern Germany (the former GDR) are almost clearly restricted emigration areas, such a correlation should be found especially in these regions. Furthermore, in North-Eastern Germany the expected relationship should be more pronounced at young adult ages, since the emigration from the former GDR started around 1990, while in Italy the most intensive population movements from the South to the Center and the North occurred in the 1960s and 1970s. Consequently, in South Italy a migration-caused selection effect should manifest in a correlation between population age and mortality at higher ages than in Germany.

Using the data for the years 1997 to 1999 on Italian and German district level we found that among women and men in South Italy as well as among men in North-Eastern 
Germany the expected correlation exists with high statistically significance. Among the districts in both regions life expectancy at birth is the lower the younger the populations are. Also regarding the correlation between population age and age-specific mortality, the basic hypothesis was strongly supported with a high statistically significant relationship among younger adult ages in North-Eastern Germany and among higher adult ages in South Italy. Only among North-Eastern German women no statistically significant relationship between population age and mortality could be found. Anyway, the directions of the correlation also fit to the basic hypothesis. That in this case the expected correlation is not statistically significant could be explained by the fact that female migration generally arises some years after male migration and thus the ten years of emigration from North Eastern Germany could be too less for producing a statistically significant migration-caused selection effect among women.

It is the question if we should expect the contrary relationship between mortality and population age in the other regions, namely North and Center Italy, and North-West and South Germany. The answer is no, since immigration areas in both countries are not as clearly geographically restricted as the emigration areas. To figure out a positive migration-caused selection effect in immigration areas it is necessary to concentrate on immigration districts only. The areas of North and Center Italy as well as North-West and South Germany are too heterogeneous regarding migration history to expect such a clear relationship between mortality and population age. But keeping in mind the results of South Italy and North-Eastern Germany it is very likely that at least some of the found correlation between population age and mortality in the other regions are due the healthy migrant phenomenon. One of the next steps of this research project will be the necessary creation of pure immigration areas among Italian and German districts connected with a deeper analysis of their immigration history. Additionally, in contrary to the emigration areas of South Italy and North-East Germany it is necessary to include also international migration in the theoretical framework. 
Anyway, the results of this study provide very strong evidence that a migration-caused selection effect affecting regional mortality differences in Italy and in Germany is indeed existing, with a stronger impact in Italy as compared to Germany. To quantify this effect more generally it is necessary to further distinguish subgroups also among the emigration areas and to find an appropriate statistical model for describing the statistical relationship. Including a time perspective will also be one of the necessary future steps as well as to figure out the main causes of death among which this selection effect is most effective. The aim of this paper so far is solely to find an easy indicator to test the hypothesis of an existing migration-caused selection effect. The found correlation between mortality and population age in both South Italy and North-Eastern Germany are stronger than expected. Consequently, the hypothesis of a migration-caused selection effect affecting regional mortality differences can't be rejected. The healthy migrant phenomenon and the salmon bias obviously belong to the group of general factors that are responsible for the existence of regional differences in survival conditions even on the macro level and that work independently from the societal and economic background of the regions.

\section{References}

Ascoli, U., 1979: Movimenti migratori in Italia, Il Mulino.

Abraido-Lanza, A. F.; Dohrenwend, B. P.; Ng-Mak, D. S.; Turner, J. B., 1983: "The Latino mortality paradox: A test of the 'salmon bias' and healthy migrant hypothesis", American Journal of Public Health 89 (10): 1543-1548.

Adelstein, A. M.; Marmot, M. G.; Dean, G.; Bradshaw, J. S. (1986): “Comparison of mortality of Irish immigrants in England and Wales with that of Irish and British nationals", Irish Medical Journal 79 (7): 185-189.

Balarajan, R.; Raleigh, V. S., 1997: "Patterns of mortality among Bangladeshis in England and Wales", Ethnicity \& Health 2 (1-2): 5-12. 
Barbone, F.; Filiberti, R.; Franceschi, S.; Talamini, R.; Conti, E.; Montella, M.; La Vecchia, C., 1996: "Socioeconomic status, migration and the risk of breast cancer in Italy", International Journal of Epidemiology 25 (3): 479-487.

Billeter, E. P., 1954: “Eine Maßzahl zur Beurteilung der Altersverteilung einer Bevölkerung”, Schweizerische Zeitschrift für Volkswirtschaft und Statistik 90: 496-505.

Brimblecombe, N.; Dorling, D.; Shaw, M., 2000: "Migration and geographical inequalities in health in Britain", Social Science and Medicine 50: 861-878.

Bucher, H., 2002: "Die Sterblichkeit in den Regionen der Bundesrepublik Deutschland und deren Ost-West-Lücke seit der Einigung”, pp. 33-38 in Cromm, J. and R. Scholz (eds.), Regionale Sterblichkeit in Deutschland, Augsburg, Göttingen: WiSoMed.

Buiatti, E., Geddes, M.; Kriebel, D.; Santucci, M.; Biggeri, A., 1985: “A case control study of lung cancer in Florence, Italy: II. Effect of migration from the south", Journal of Epidemiology \& Community Health 39 (3): 251-255.

Caselli, G.; Egidi, V., 1980: Le differenze territoriali di mortalità in Italia. Tavole di mortalità provinciali (1971-72), Roma: Istituto di Demografia dell’Università.

Caselli, G.; Reale, A., 1999: "Does cohort analysis contribute to the study of the geography of mortality?", Genus 55 (1-2): 27-59.

Caselli, G.; Vallin, J., 2002: “Les variations géographiques de la mortalité”, pp. 373-415 in Caselli, G.; Vallin, J.; Wunsch, G. (eds.), Démographie: analyse et synthèse III, les déterminants de la mortalité, Paris: INED.

Caselli, G.; Cerbara, L.; Heins, F.; Lipsi, R. M., 2003: "What impact do contextual variables have on the changing geography of mortality in Italy?", European Journal of Population 19: 339-373.

Ceppi, M.; Vercelli, N.; Decarli, A.; Puntoni, R., 1995: "The mortality rate of the province of birth as a risk indicator for lung and stomach cancer mortality among Genoa residents born in other Italian provinces”, European Journal of Cancer 31 (2): 193-197. 
Coggon, D.; Osmond, C.; Barker, D. J., 1990: “Stomach cancer and migration within England and Wales", British Journal of Cancer 61 (4): 573-574.

Dinkel, R. H., 1989: Demographie. Band 1: Bevölkerungsdynamik. München: Vahlen.

Dinkel, R. H.; Lebok, U., 1997: "Demographische Alterung in den alten und neuen Ländern Deutschlands", Geographische Rundschau 3: 169-172.

Eberstadt, N., 1994: "Demographic shocks after communism: Eastern Germany, 1989-93”, Population and Development Review 20 (1): 137-152.

Elford, J.; Phillips, A.; Thomson, A. G.; Shaper, A. G., 1990: "Migration and geographic variations in blood pressure in Britain", British Medical Journal (Clinical Research Ed.) 300 (6720): 291-295.

Fascioli, S.; Capocaccia, R.; Mariotti, S., 1995: "Cancer mortality in migrant populations within Italy", International Journal of Epidemiology 24 (1): 8-18.

Feinleib, M.; Hunt, B. M.; Ingster-Moore, L.; Haenszel, W. D.; Lambert, P. M.; ZeinerHenriksen, T.; Rogot, E., 1981: "The British-Norwegian migrant study - analysis of parameters of mortality differentials associated with angina", Biometrics 38 , supplement: 55-74

Golini, A., 1974: Distribuzione della popolazione, migrazioni interne e urbanizzazione in Italia, Istituto di Demografia, Università degli Studi di Roma.

Greenberg, M.; Schneider, D., 1995: Migration and the cancer burden of New jersey Blacks", New Jersey Medicine 92 (8): 509-511.

Gröner, G., 2002: “Zu Entwicklung und regionalen Unterschieden der Sterblichkeit in BadenWürttemberg um 1990”, pp. 39-64 in Cromm, J.; Scholz, R. D. (eds.), Regionale Sterblichkeit in Deutschland, Augsburg and Göttingen: WiSoMed, Cromm.

Harding, S.; Maxwell, R., 1998: "Differences in the mortality of migrants", in Drever, F. and M. Whitehead (Eds.), Health Inequalities, London: ONS. 
Heigl, A., 1998: Determinanten regionaler Altersstrukturdifferenzen in Bayern. Eine soziodemographische Analyse. Frankfurt am Main et al.: Lang.

Heigl, A.; Mai, R., 1998: "Demographische Alterung in den Regionen der EU”, Zeitschrift für Bevölkerungswissenschaft 23 (3): 293-317.

Heinemann, L.; Dinkel, R.; Görtler, E., 1996: “Life expectancy in Germany: possible reasons for the increasing gap between East and West Germany", Reviews on Environmental Health 11 (1-2): 15-26.

Höhn, C.; Pollard, J., 1991: "Mortality in the two Germanies in 1986 and trends 1976-1986", European Journal of Population 7: 1-28.

King, H.; Locke, F. B., 1987: "Health effects of migration: U.S. Chinese in and outside the Chinatown”, International Migration Review 21 (3): 555-575.

Kington, R.; Carlisle, D.; McCaffrey, D.; Myers, H.; Allen, W., 1998: "Racial differences in functional status among elderly U.S. migrants from the south", Social Science \& Medicine 47 (6): 831-840.

Lanska, D. J.; Peterson, P. M., 1995: "Effects of interstate migration on the geographic distribution of stroke mortality in the United States", Stroke 26 (4): 554-561.

Lee, W. R., 1984: "Mortality levels and agrarian reform in early $19^{\text {th }}$ century Prussia. Some regional evidence”, pp. 161-190 in Bengtsson, T., Fridlizius, G. and R. Ohlsson (eds.), Pre-industrial population change. The mortality decline and short-term population movements, Stockholm, Almquist and Wiksell International.

Lipsi, R. M.; Caselli, G., 2002: Evoluzione della geografia della mortalità in Italia. Tavole provinciali e probabilità di morte per causa, anni: 1971-1973, 1981-1983, 1991-1993, Rome: Dipartimento di Scienze Demografiche.

Luy, M., 2003: Mortality in Eastern and Western Germany before and after reunification new insights from the German Life Expectancy Survey, paper presented at the 2003 PAA Annual Meeting, Minneapolis, Minnesota. 
Luy, M., 2004a: Mortalitätsanalyse im Bereich der Historischen Demographie - die Erstellung von Periodensterbetafeln unter Anwendung der Growth-Balance-Methode und statistischer Testverfahren, Dissertation, University of Rostock.

Luy, M., 2004b: "Verschiedene Aspekte der Sterblichkeitsentwicklung in Deutschland von 1950 bis 2000”, Zeitschrift für Bevölkerungswissenschaft 29 (1): in press.

Mai, R., 2003a: Abwanderung aus Ostdeutschland. Strukturen und Milieus der Altersselektivität und ihre regionalpolitische Bedeutung. Frankfurt am Main et al.: Lang.

Mai, R., 2003b: Die Alten der Zukunft. Eine bevölkerungsstatistische Datenanalyse, Opladen: Leske + Budrich

Mancuso, T. F., 1977: "Lung cancer among black migrants. Interaction of host and occupational environment factors", Journal of Occupational Medicine 19 (8): 531-532.

McKay, L.; Macintyre, S.; Ellaway, A., 2003: Migration and Health: A review of the international literature, MRC Social \& Public Health Sciences Unit, Occasional paper 12.

Mey, W., 2002: "Regionale Unterschiede der Sterblichkeit im Süden der Neuen Bundesländer”, pp. 117-127 in Cromm, J.; Scholz, R. D. (eds.), Regionale Sterblichkeit in Deutschland, Augsburg and Göttingen: WiSoMed, Cromm.

Nair, C.; Nargundkar, M.; Johansen, H.; Strachan, J., 1990: “Canadian cardiovascular disease mortality: first generation immigrants versus Canadian born", Health Reports 2 (3): 203-228.

Nolte, E.; Shkolnikov, V.; McKee, M., 2000a: "Changing mortality patterns in East and West Germany and Poland. I: Long-term trends”, Journal of Epidemiology and Community Health 54: 890-899.

Nolte, E.; Shkolnikov, V.; McKee, M., 2000b: "Changing mortality patterns in East and West Germany and Poland. II: Short-term trends during transition and in the 1990s", Journal of Epidemiology and Community Health 54: 899-906. 
Palloni, A.; Arias, E., 2003: A re-examination of the Hispanic mortality paradox, CDE Working Paper 2003-01.

Paul, C., 1992: “Sterblichkeit im regionalen Vergleich. Allgemeine Sterbetafeln der elf alten Bundesländer”, Wirtschaft und Statistik: 82-87.

Preston, S. H.; Heuveline, P.; Guillot, M., 2001: Demography. Measuring and modeling population processes, Oxford: Blackwell.

Raftery, J.; Jones, D. R.; Rosato, M., 1990: "The mortality of first and second generation Irish immigrants in the U.K.”, Social Science and Medicine 31 (5): 577-584.

Razum, O.; Zeeb, H.; Gerhardus, A., 1998a: “Cardiovascular mortality of Turkish nationals residing in West Germany", Annals of Epidemiology 8 (5): 334-341.

Razum, O.; Zeeb, H.; Akgün, H. S.; Yilmaz, S., 1998b: "Low overall mortality of Turkish residents in Germany persists and extends into a second generation: merely a healthy migrant effect?", Tropical Medicine and International Health 3 (4): 297-303.

Roloff, J., 2000: Die demographische Entwicklung in den Bundesländern Deutschlands. Materialien zur Bevölkerungswissenschaft 100. Wiesbaden: Bundesinstitut für Bevölkertungsforschung.

Scholz, R. D.; Thoelke, H., 2002: „Lebenserwartung in Berlin 1986 bis 1996 - Trends und regionale Unterschiede“, pp. 65-83 in Cromm, J.; Scholz, R. D. (eds.), Regionale Sterblichkeit in Deutschland, Augsburg and Göttingen: WiSoMed, Cromm.

Shai, D.; Rosenwaike, E., 1987: "Mortality among Hispanics in metropolitan Chicago: an examination based on vital statistics data", Journal of Chronic Diseases 40 (5): 445451.

Sharma, R. D.; Michalowski, M.; Verma, R. B. P., 1990: "Mortality differentials among immigrant populations in Canada", International Migration 28 (4): 443-450.

Singh, G. K.; Siahpush, M., 2001: “All-cause and cause-specific mortality of immigrants and native born in the United States", American Journal of Public Health 91 (3): 392-399. 
Sommer, B., 1998: "Die Sterblichkeit in Deutschland im regionalen und europäischen Vergleich", Wirtschaft und Statistik: 960-970.

Sommer, B., 2002: "Die Sterblichkeit in der Bunderepublik Deutschland in der Regionalisierung der Länder”, pp. 18-32 in Cromm, J. and R. Scholz (eds.), Regionale Sterblichkeit in Deutschland, Augsburg, Göttingen: WiSoMed.

Strachan, D. P.; Leon, D. A.; Dodgeon, B., 1995: "Mortality from cardiovascular disease among interregional migrants in England and Wales [see comments]", British Medical Journal (Clinical Research Ed.) 310 (6977): 423-427.

Toniolo, P.; Protta, F.; Cappa, A. P. M., 1989: "Risk of breast cancer, diet and internal migration in Northern Italy", Tumori 75 (5): 406-409.

Tsugane, S.; Gotlieb, S. L.; Laurenti, R.; Souza, J. M. P.; Watanabe, S., 1989: "Mortality and cause of death among first-generation Japanese in Sao Paulo, Brazil”, International Journal of Epidemiology 18 (3): 647-651.

Valkonen, T.; Brancker, A.; Reijo, M., 1992: "Mortality differentials between three populations - residents of Scandinavia, Scandinavian immigrants to Canada and Canadianborn residents of Canada, 1979-1985", Health Reports 4 (2): 137-159.

Van Steenbergen, J. E.; Schulpen, T. W. J.; Hoogenboezem, J.; Van Driel, H. F.; Bijlsma, F., 1999: "Ethnicity and childhood mortality in the Netherlands", European Journal of Public Health 9 (3): 205-210.

Vaupel, J. W., 2002: "Life expectancy at current rates vs. current conditions. A reflexion stimulated by Bongaarts and Feeney's 'how long do we live?', Demographic Research 7: $365-377$.

Vaupel, J. W.; Carey, J. R.; Christensen, K., 2003: “It's never too late”, Science 301: 16791681. 
Vigotti, M. A.; Cislaghi, C.; Balzi, D.; Giorgi, D.; La Vecchia, C.; Marchi, M.; Decarli, A.; Zanetti, R., 1988: "Cancer mortality in migrant populations within Italy", Tumori 74 (2): 107-128.

Wei, M.; Valdez, R. A.; Mitchell, B. D.; Haffner, S. M.; Stern, M. P.; Hazuda, H. P., 1996: "Migration status, socioeconomic status, and mortality rates in Mexican Americans and non-Hispanic whites: the San Antonio Heart Study", Annals of Epidemiology 6 (4): $307-313$.

Wild, S.; McKeigue, P., 1997: "Cross sectional analysis of mortality by country of birth in England and Wales, 1970-92”, British Medical Journal 314 (7082): 705-710.

Wittwer-Backofen, U., 1999: Disparitäten der Alterssterblichkeit im regionalen Vergleich Biologische versus sozioökonomische Determinanten. Regionale Studie für den Raum Hessen, Materialen zur Bevölkerungswissenschaft 95, Wiesbaden: BiB. 


\section{Figures and Tables}

Fig. 1: Regional mortality differences in life expectancy at birth for Italian men, measured for

"Regioni" classified in units of the standard deviation $(\sigma=0.64)$

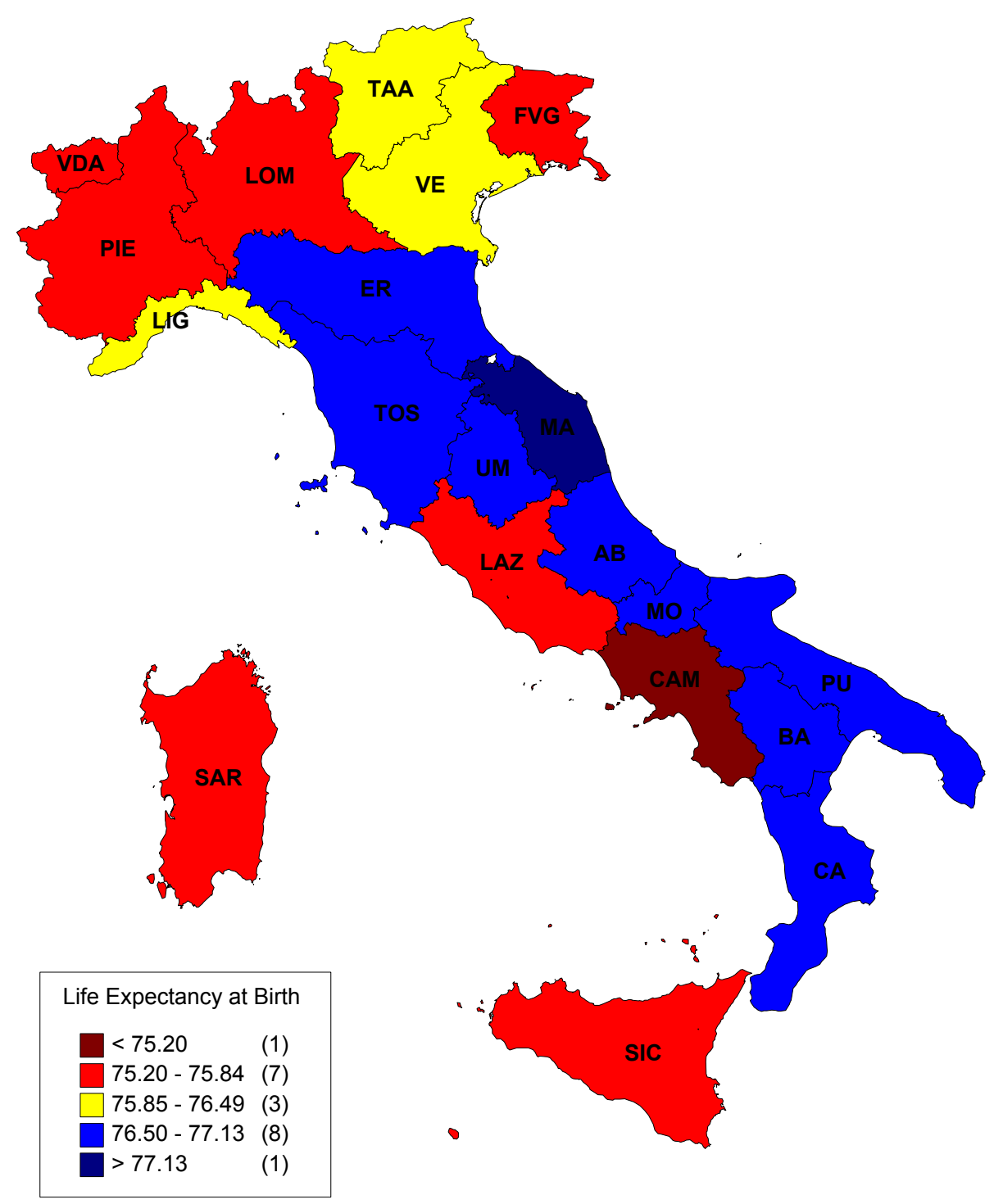

TAA: Trentino-Alto Adige, VDA: Valle D’Aosta, LOM: Lombardia, VE: Veneto, FVG: Friuli - Venezia Giulia, PIE: Piemonte, LIG: Liguria, ER: Emilia Romagna, TOS: Toscana, UM: Umbria, MA: Marche, LAZ: Lazio, AB: Abruzzo, MO: Molise, CAM: Campania, PU: Puglia, BA: Basilicata, CA: Calabria, SIC: 
Fig. 2: Regional mortality differences in life expectancy at birth for Italian women, measured for "Regioni" classified in units of the standard deviation $(\sigma=0.64)$

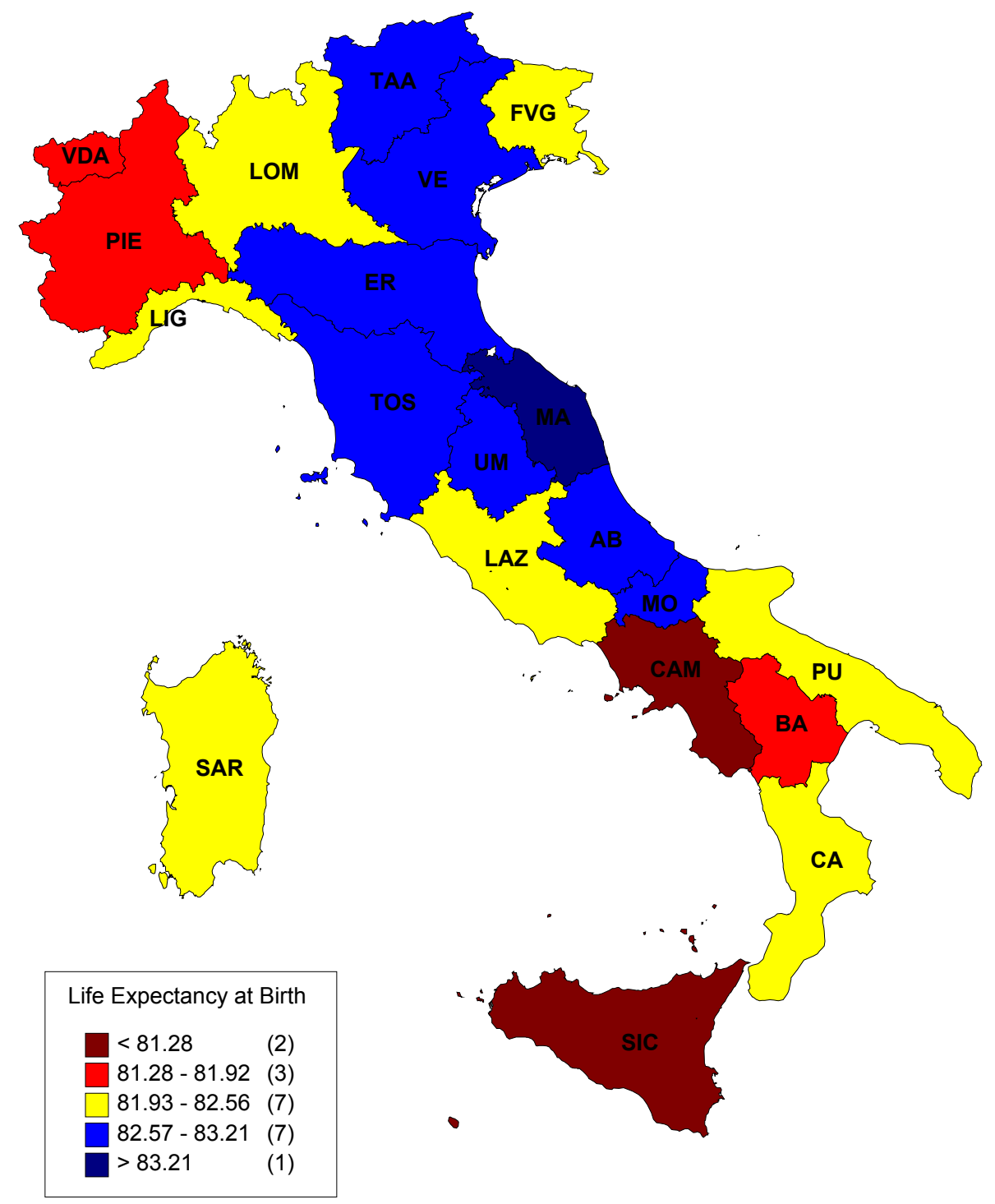

TAA: Trentino-Alto Adige, VDA: Valle D’Aosta, LOM: Lombardia, VE: Veneto, FVG: Friuli - Venezia Giulia, PIE: Piemonte, LIG: Liguria, ER: Emilia Romagna, TOS: Toscana, UM: Umbria, MA: Marche, LAZ: Lazio, AB: Abruzzo, MO: Molise, CAM: Campania, PU: Puglia, BA: Basilicata, CA: Calabria, SIC: Sicilia, SAR: Sardegna 
Fig. 3: Regional mortality differences in life expectancy at birth for German men, measured for "Bundesländer" classified in units of the standard deviation $(\sigma=1.15)$

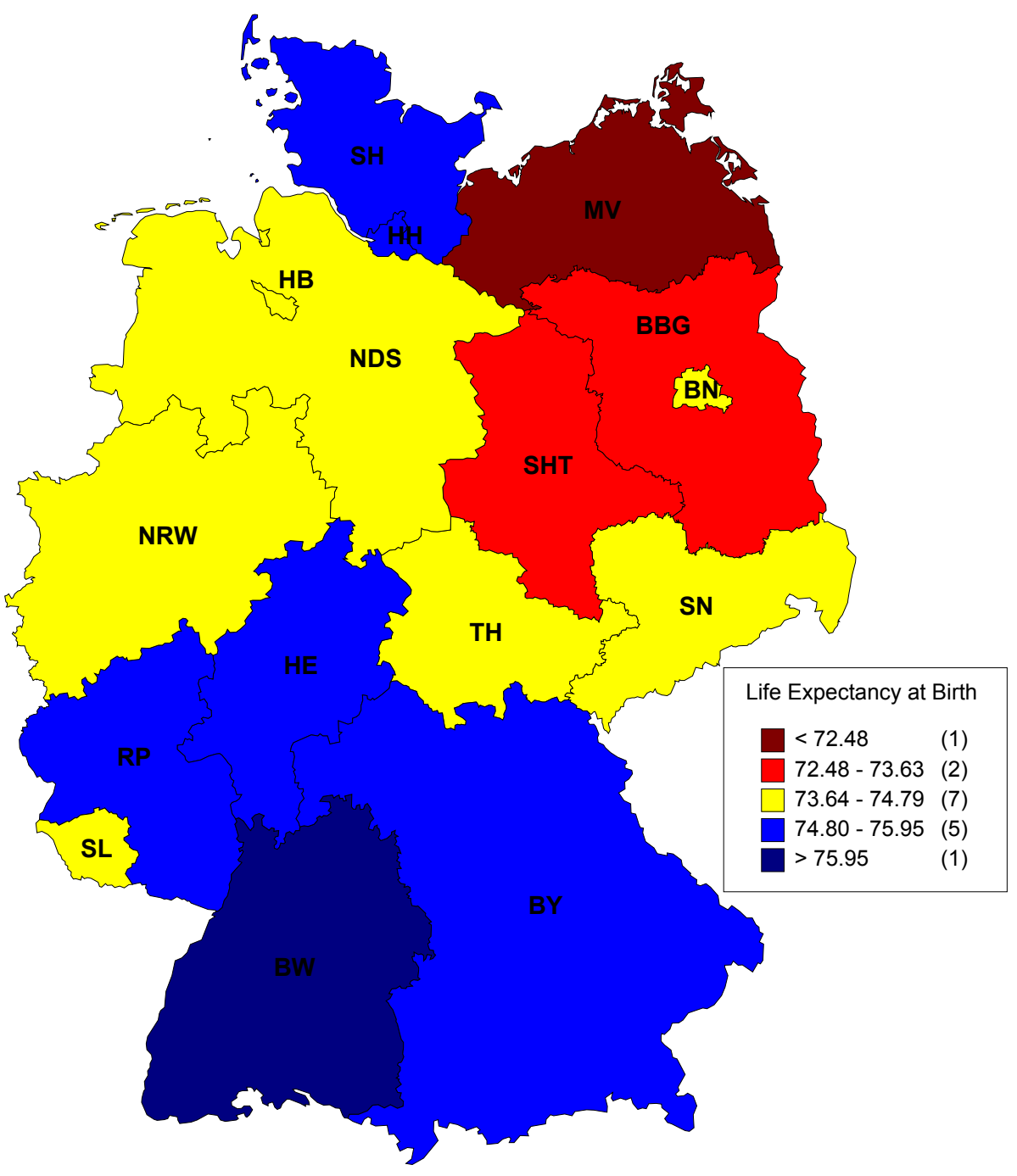

SH: Schleswig-Holstein, HH: Hansestadt Hamburg, MV: Mecklenburg-Vorpommern, HB: Hansestadt Bremen, NDS: Niedersachsen, SHT: Sachsen-Anhalt, BBG: Brandenburg, BN: Berlin, NRW: Nordrhein-Westfalen, TH: Thüringen, SN: Sachsen, RP: Rheinland-Pfalz, HE: Hessen, BY: Bayern, SL: Saarland, BW: Baden-Württemberg 
Fig. 4: Regional mortality differences in life expectancy at birth for German women, measured for "Bundesländer" classified in units of the standard dev. $(\sigma=0.76)$

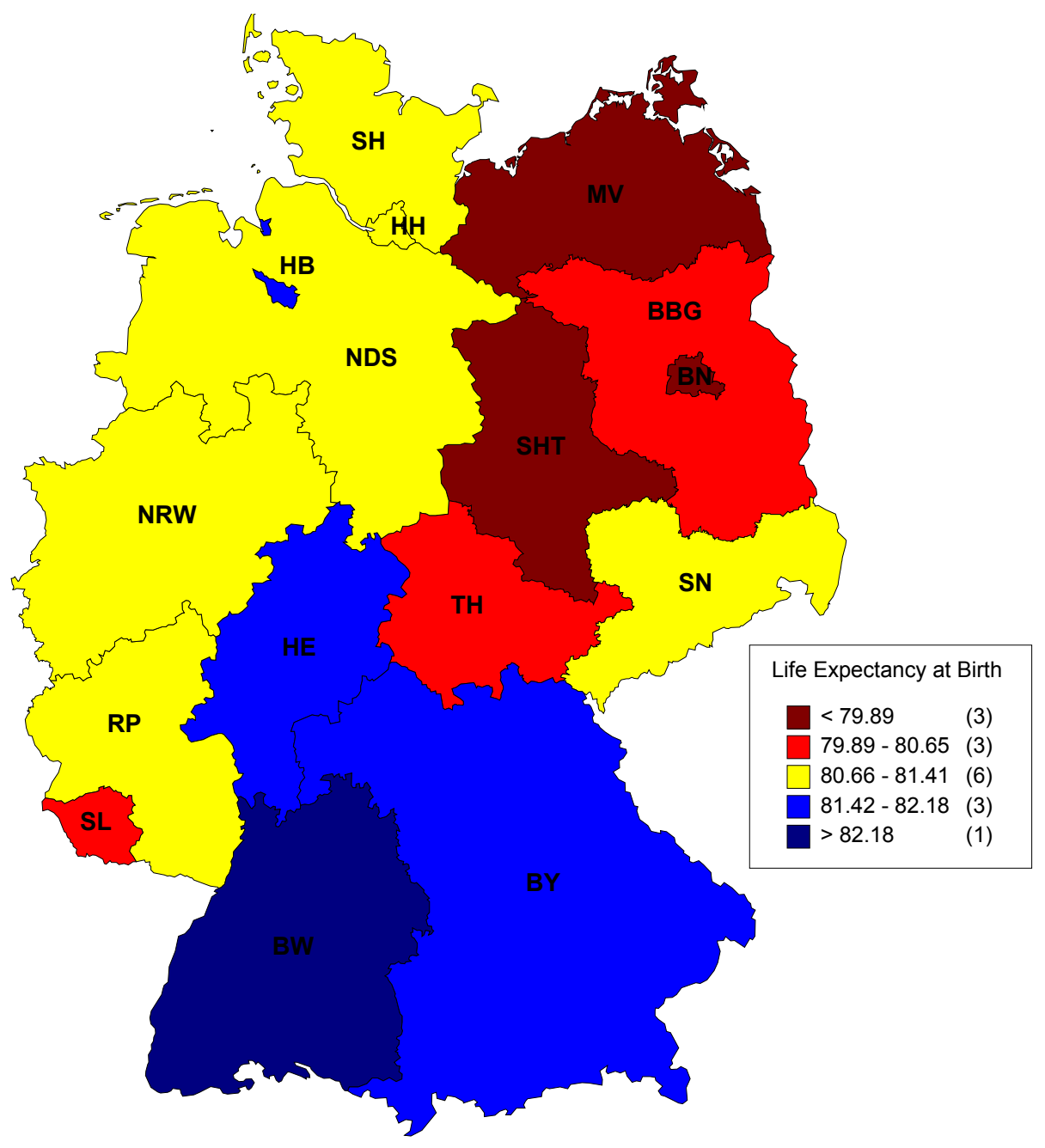

SH: Schleswig-Holstein, HH: Hansestadt Hamburg, MV: Mecklenburg-Vorpommern, HB: Hansestadt Bremen, NDS: Niedersachsen, SHT: Sachsen-Anhalt, BBG: Brandenburg, BN: Berlin, NRW: Nordrhein-Westfalen, TH: Thüringen, SN: Sachsen, RP: Rheinland-Pfalz, HE: Hessen, BY: Bayern, SL: Saarland, BW: Baden-Württemberg 
Fig.5: Age-specific number of migrants to and from Germany in 2001

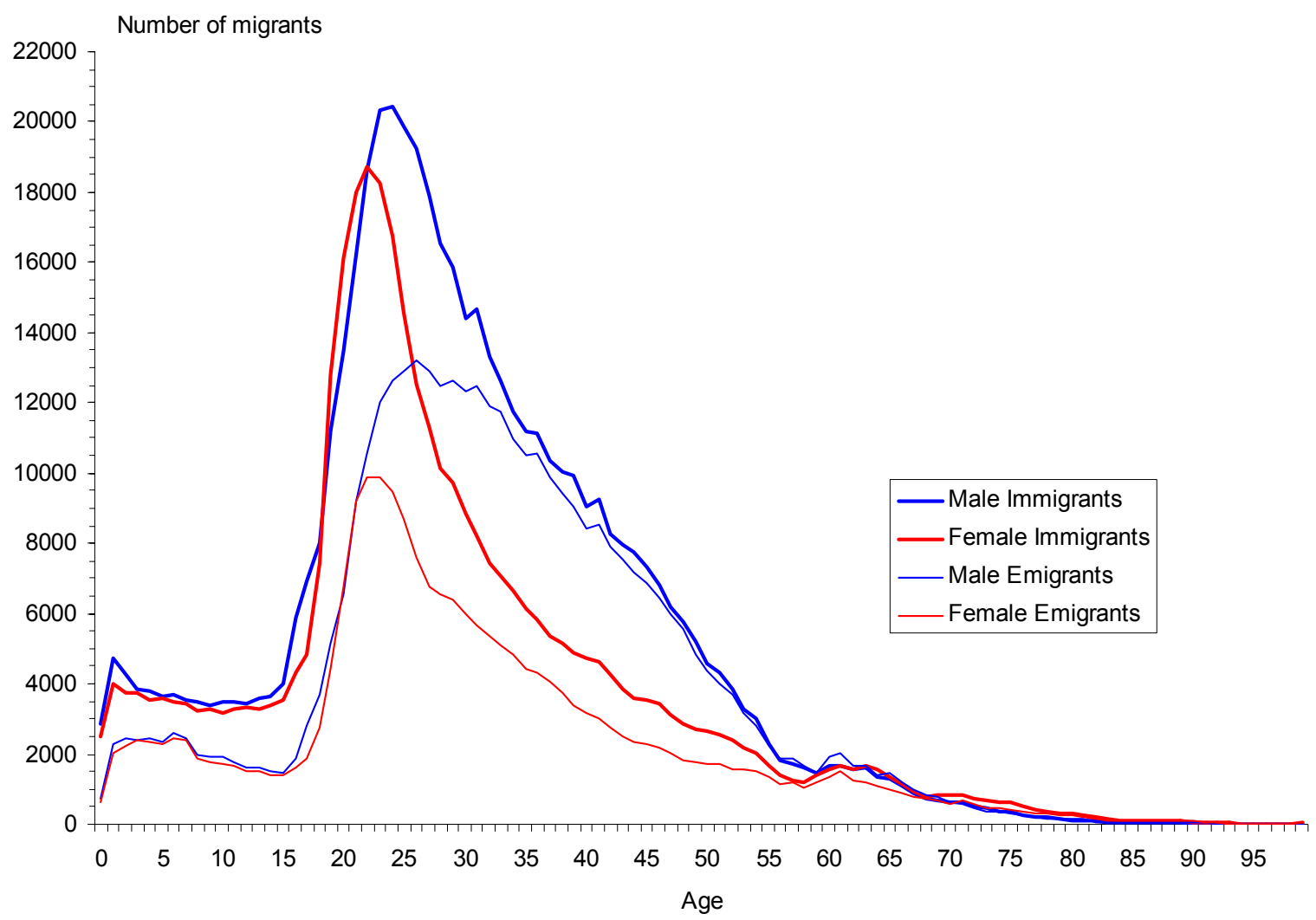


Fig. 6: Billeters' J for Italian women, measured for "Regioni" classified in units of the standard deviation $(\sigma=0.17)$

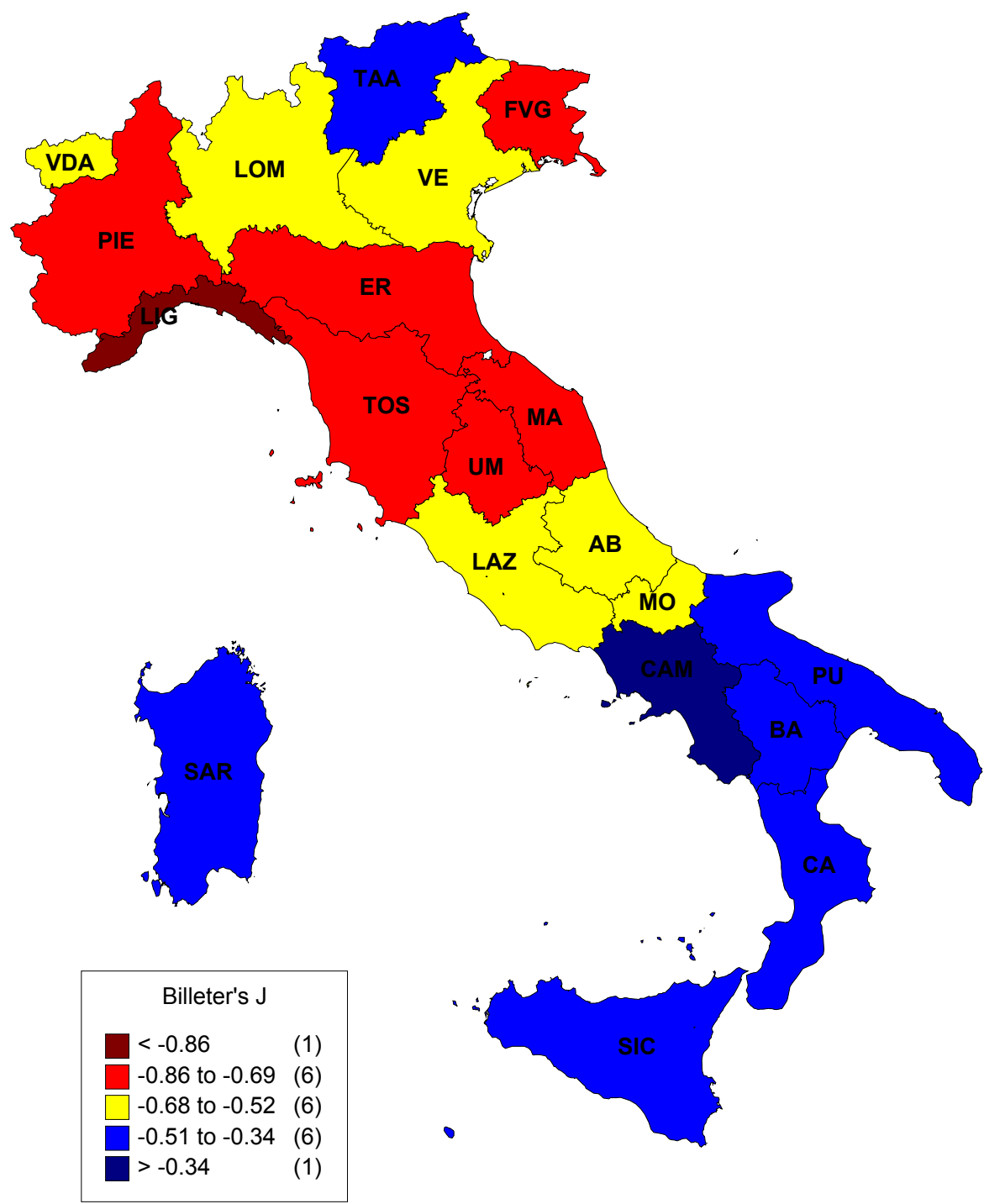

TAA: Trentino-Alto Adige, VDA: Valle D’Aosta, LOM: Lombardia, VE: Veneto, FVG: Friuli - Venezia Giulia, PIE: Piemonte, LIG: Liguria, ER: Emilia Romagna, TOS: Toscana, UM: Umbria, MA: Marche, LAZ: Lazio, AB: Abruzzo, MO: Molise, CAM: Campania, PU: Puglia, BA: Basilicata, CA: Calabria, SIC: Sicilia, SAR: Sardegna 
Fig. 7: Billeter's J for German men, measured for "Bundesländer" classified in units of the standard deviation $(\sigma=0.04)$

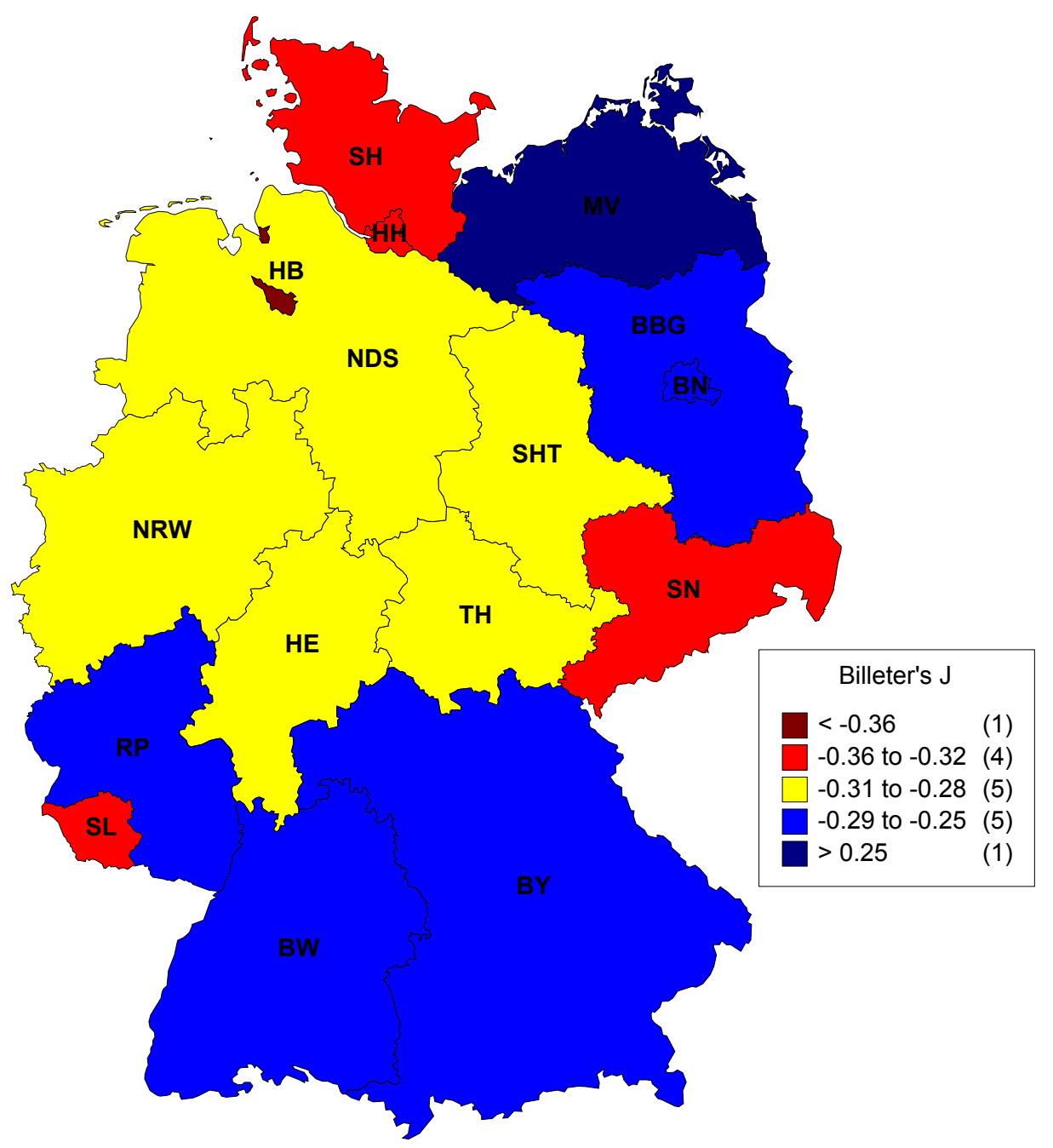

SH: Schleswig-Holstein, HH: Hansestadt Hamburg, MV: Mecklenburg-Vorpommern, HB: Hansestadt Bremen, NDS: Niedersachsen, SHT: Sachsen-Anhalt, BBG: Brandenburg, BN: Berlin, NRW: Nordrhein-Westfalen, TH: Thüringen, SN: Sachsen, RP: Rheinland-Pfalz, HE: Hessen, BY: Bayern, SL: Saarland, BW: Baden-Württemberg 
Fig. 8: Relationship between Billeter's J and life expectancy at birth e(0) for the 440 German districts with Pearson's $r$ and statistical significance, males

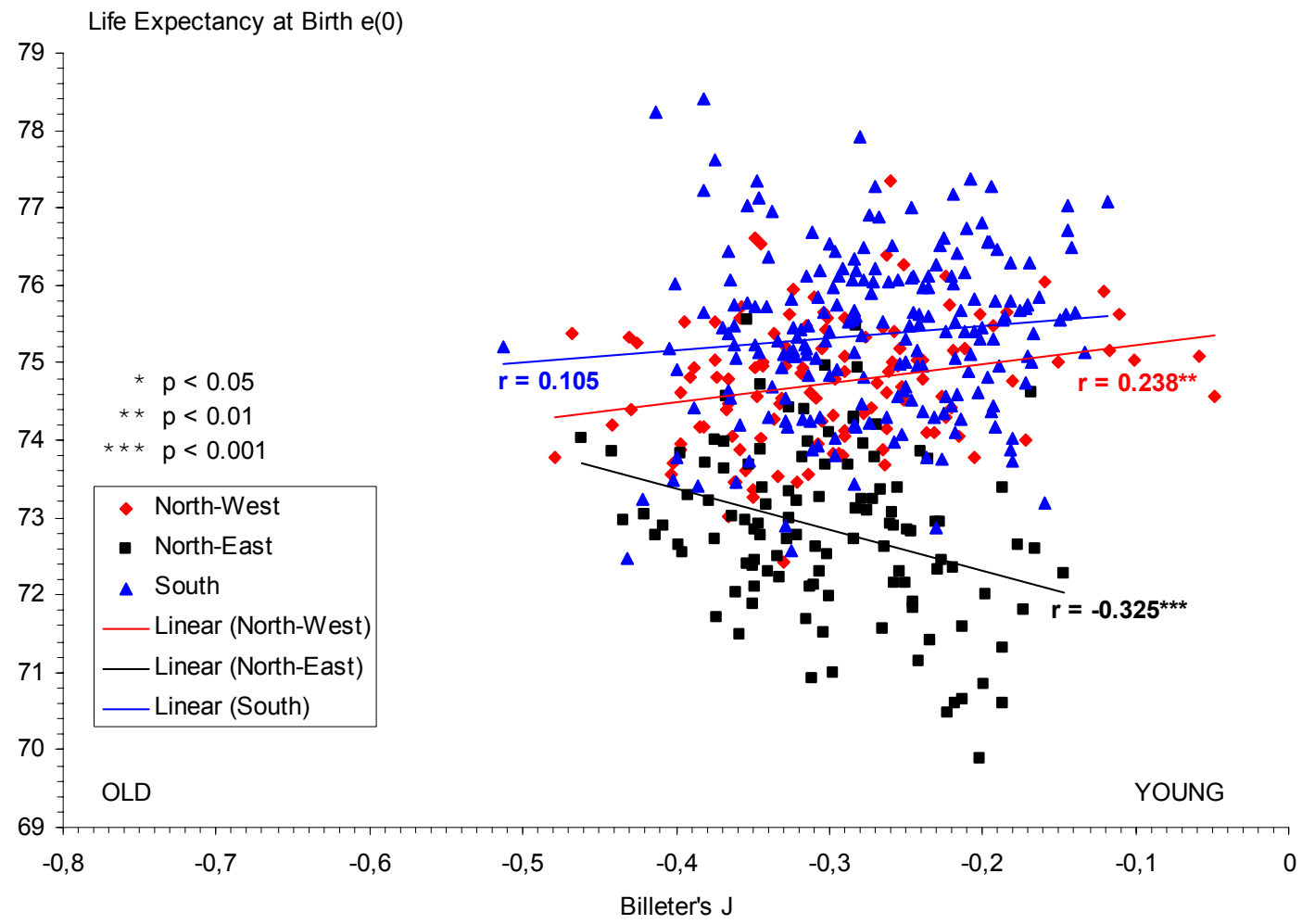

Fig. 9: Relationship between Billeter's J and life expectancy at birth e(0) for the 103 Italian districts with Pearson's $r$ and statistical significance, males

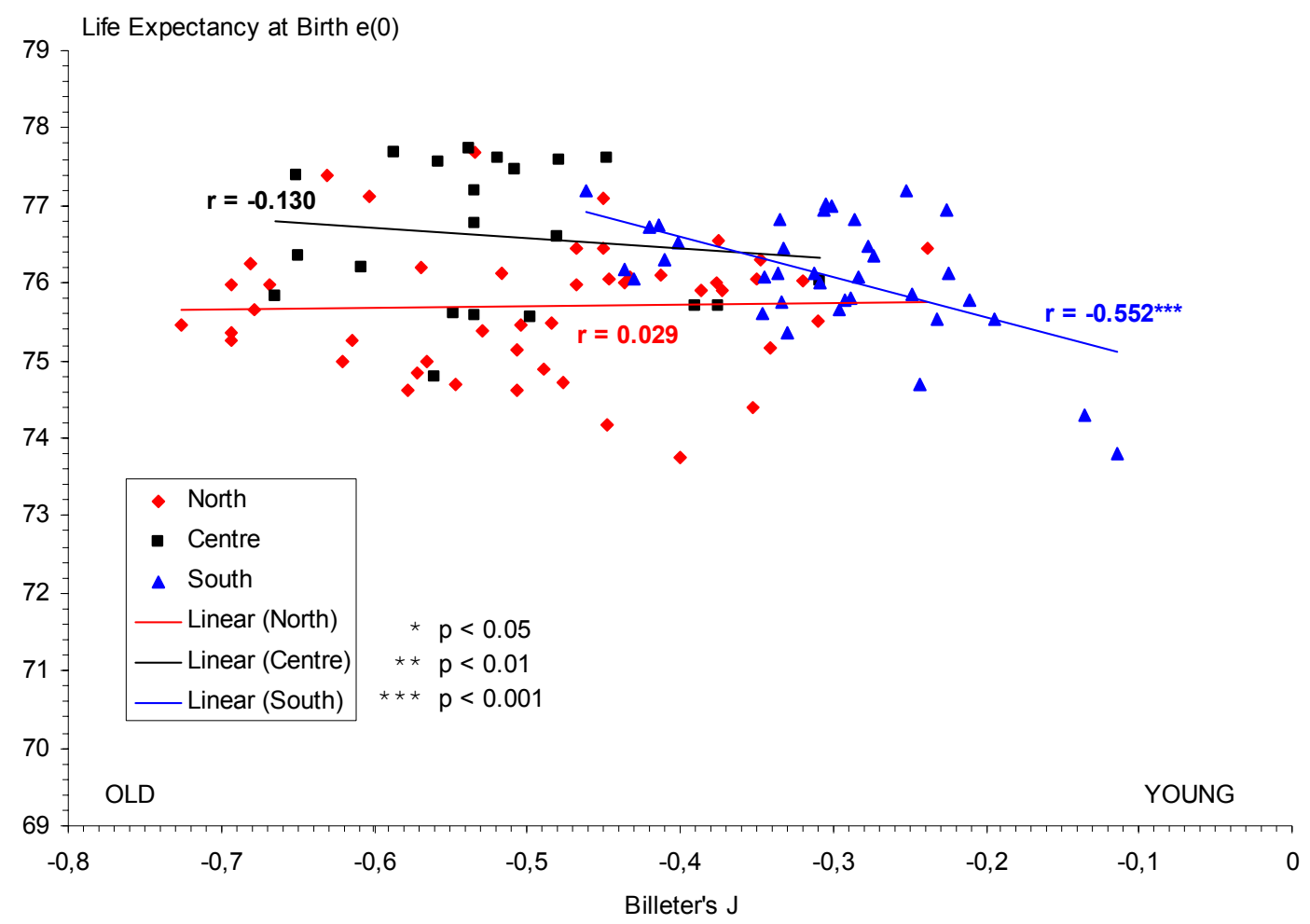


Fig. 10: Relationship between Billeter's J and probability of dying at ages $15-40{ }_{25} \mathrm{q}_{15}$ for the 440 German districts with Pearson's $r$ and statistical significance, males

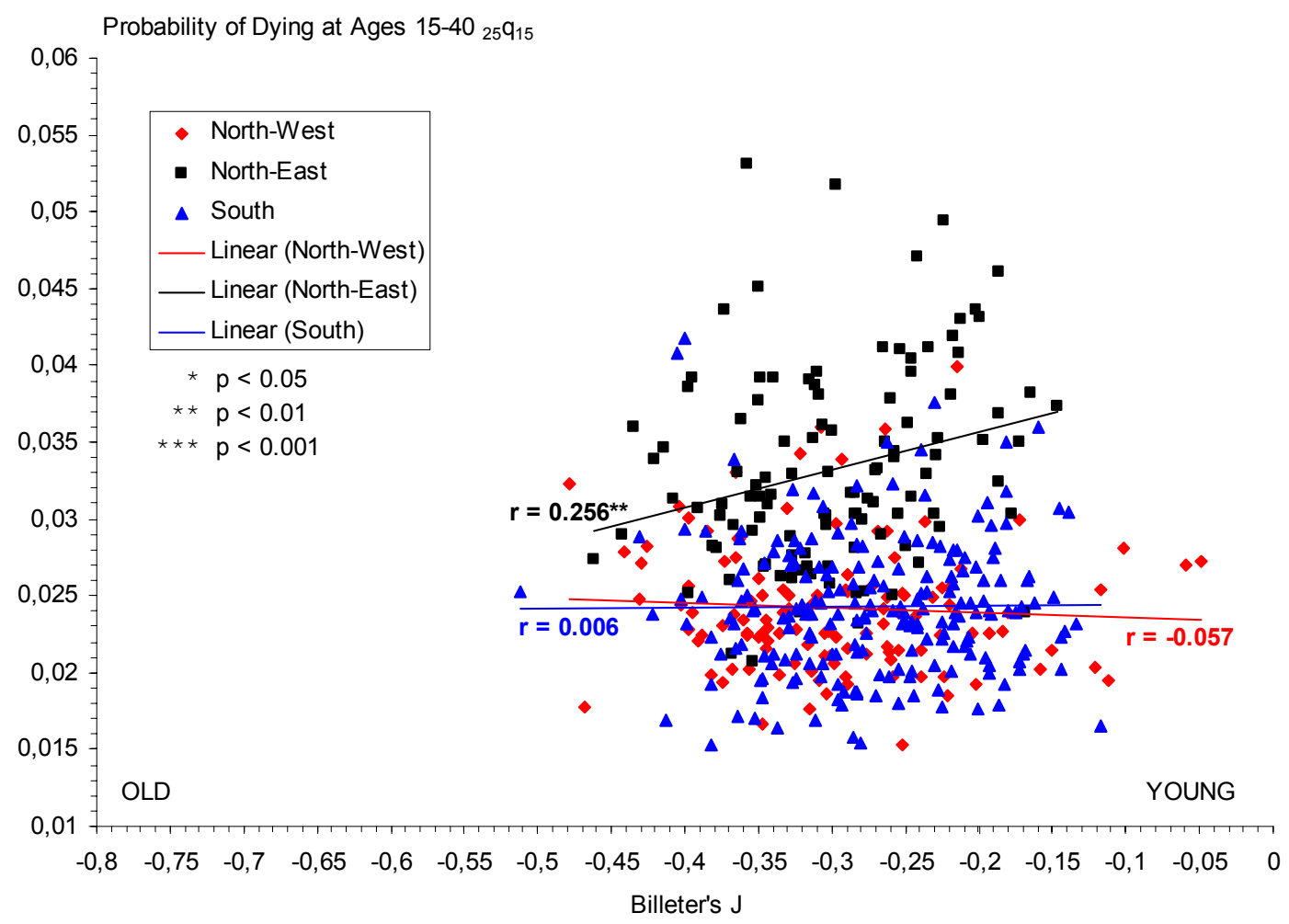

Fig. 11: Relationship between Billeter's J and probability of dying at ages $15-40{ }_{25} \mathrm{q}_{15}$ for the 103 Italian districts with Pearson's $r$ and statistical significance, males

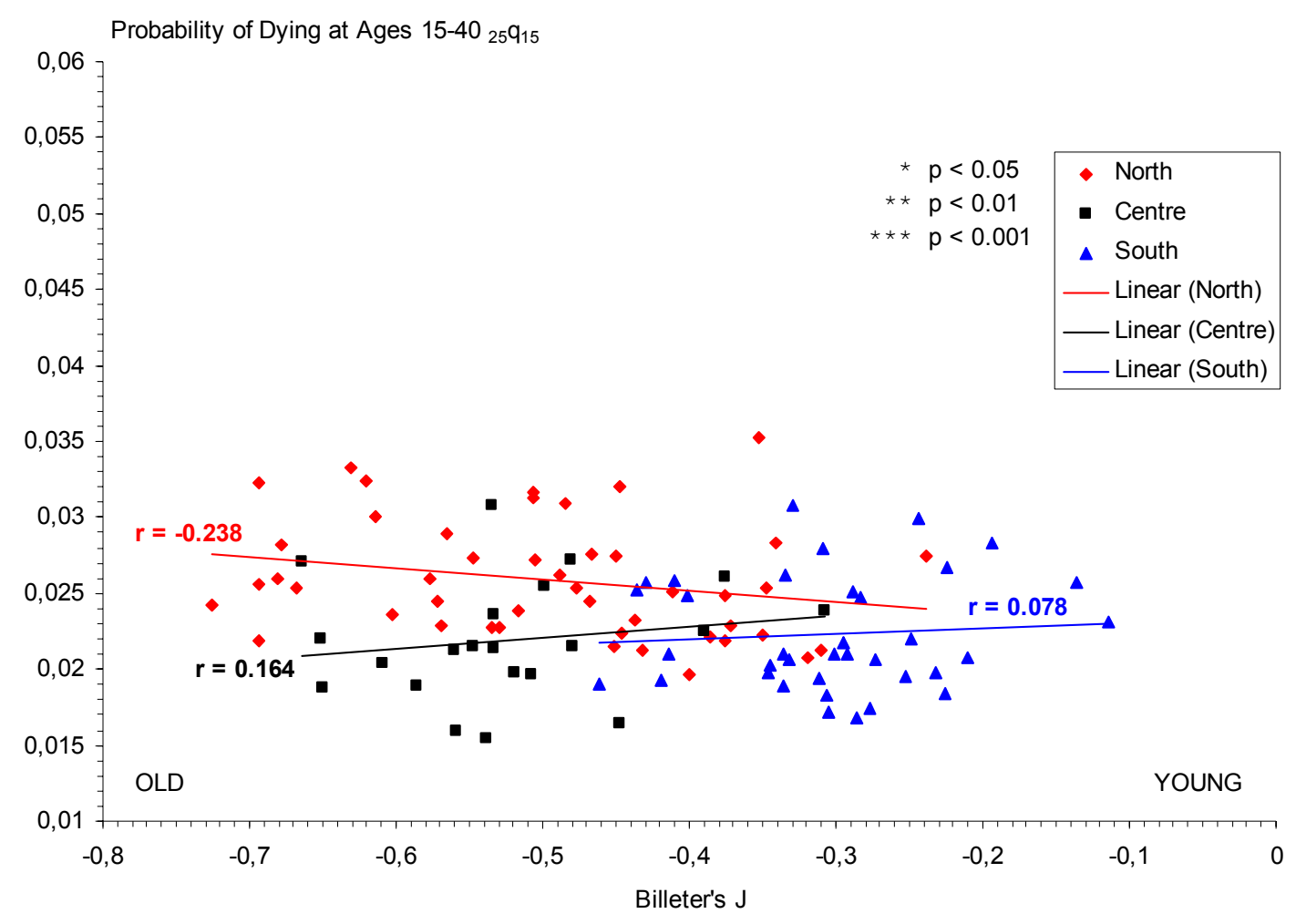


Fig. 12: Relationship between Billeter's J and probability of dying at ages 50 and $75{ }_{25} \mathrm{q}_{50}$ for the 440 German districts with Pearson's $r$ and statistical significance, males

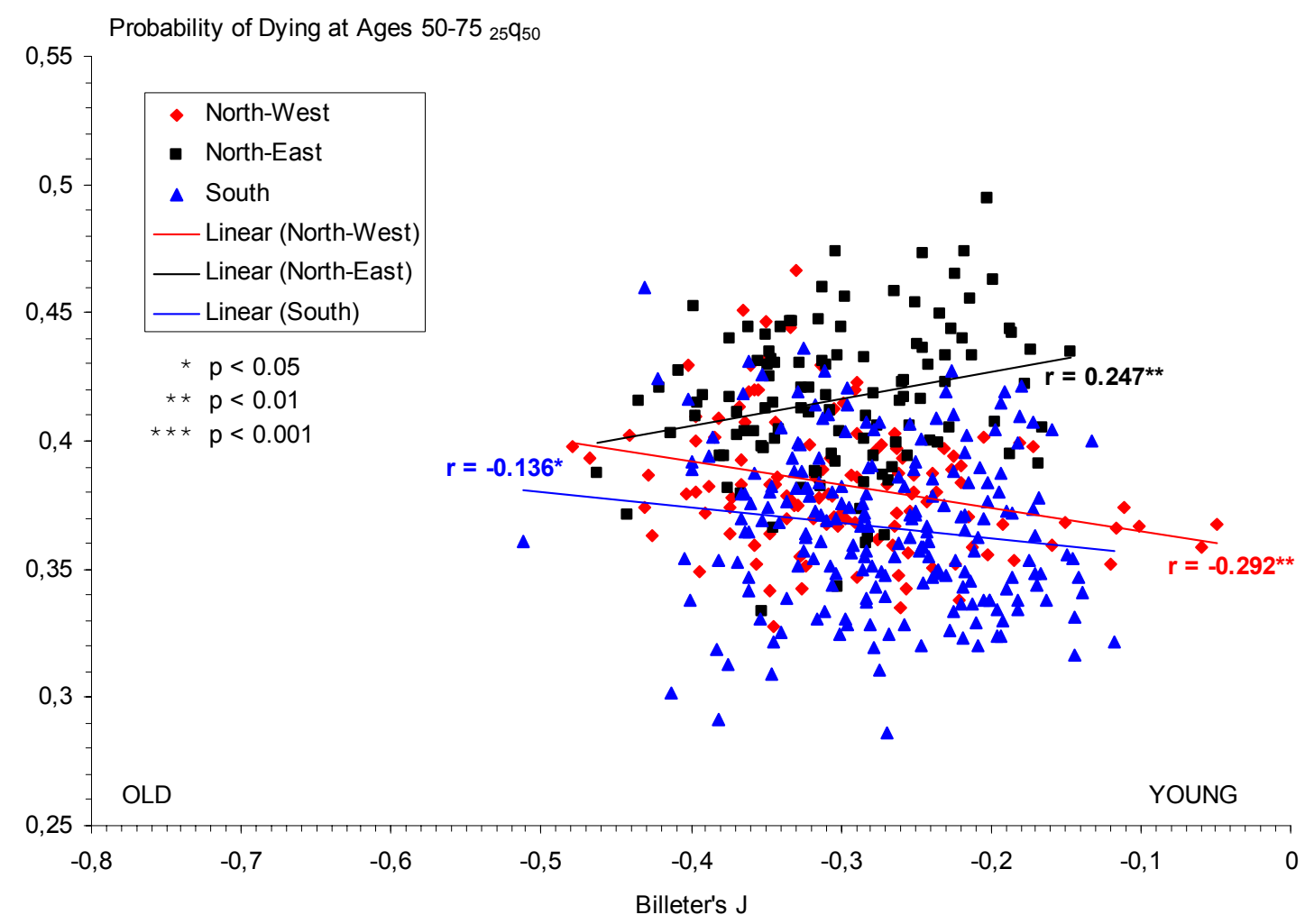

Fig. 13: Relationship between Billeter's J and probability of dying at ages $50-75{ }_{25} \mathrm{q}_{50}$ for the 103 Italian districts with Pearson's $r$ and statistical significance, males

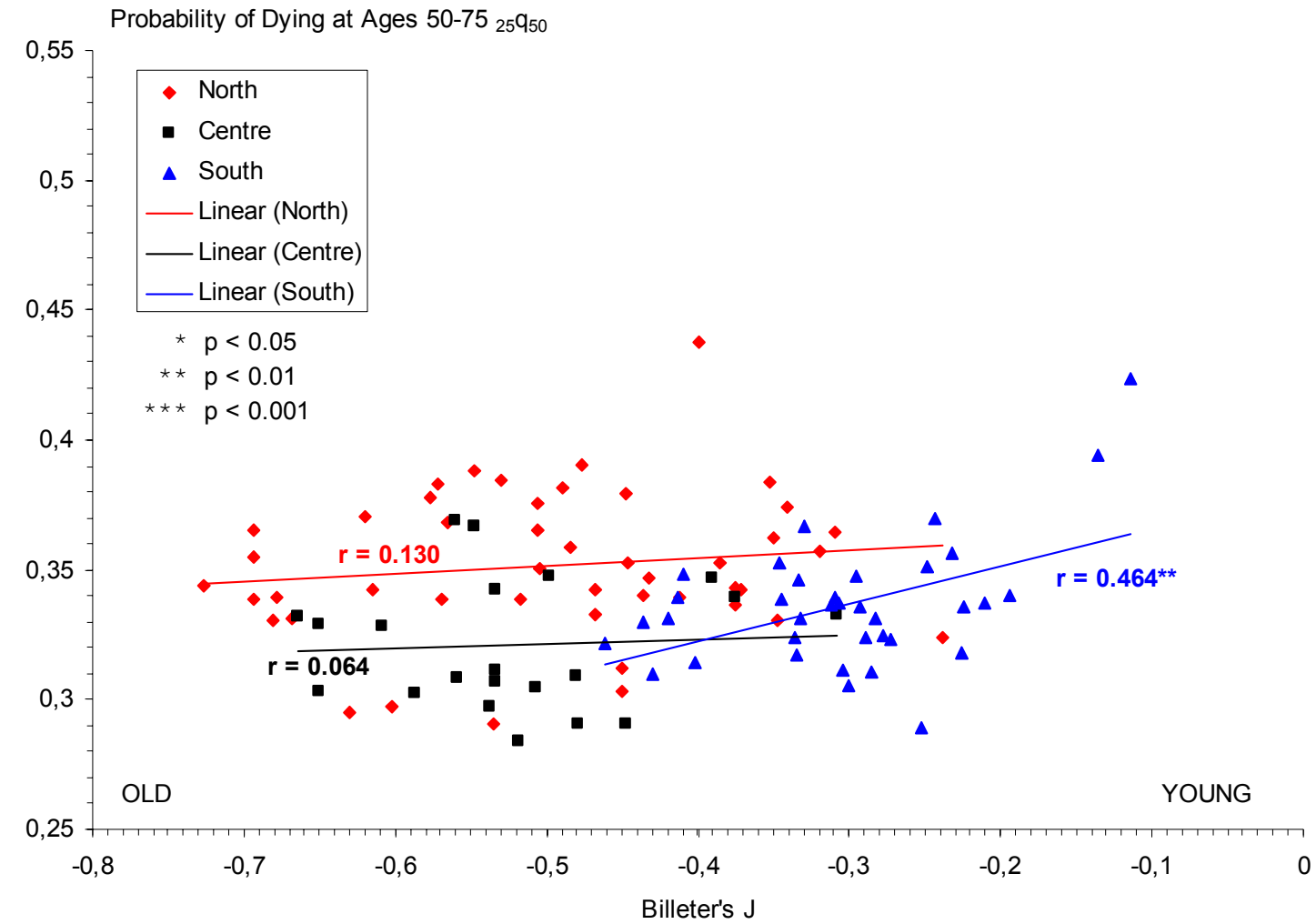


Fig. 14: Relationship between Billeter's J and death rate at ages $75+(* 1000)$ for the 440

German districts with Pearson's $r$ and statistical significance, males

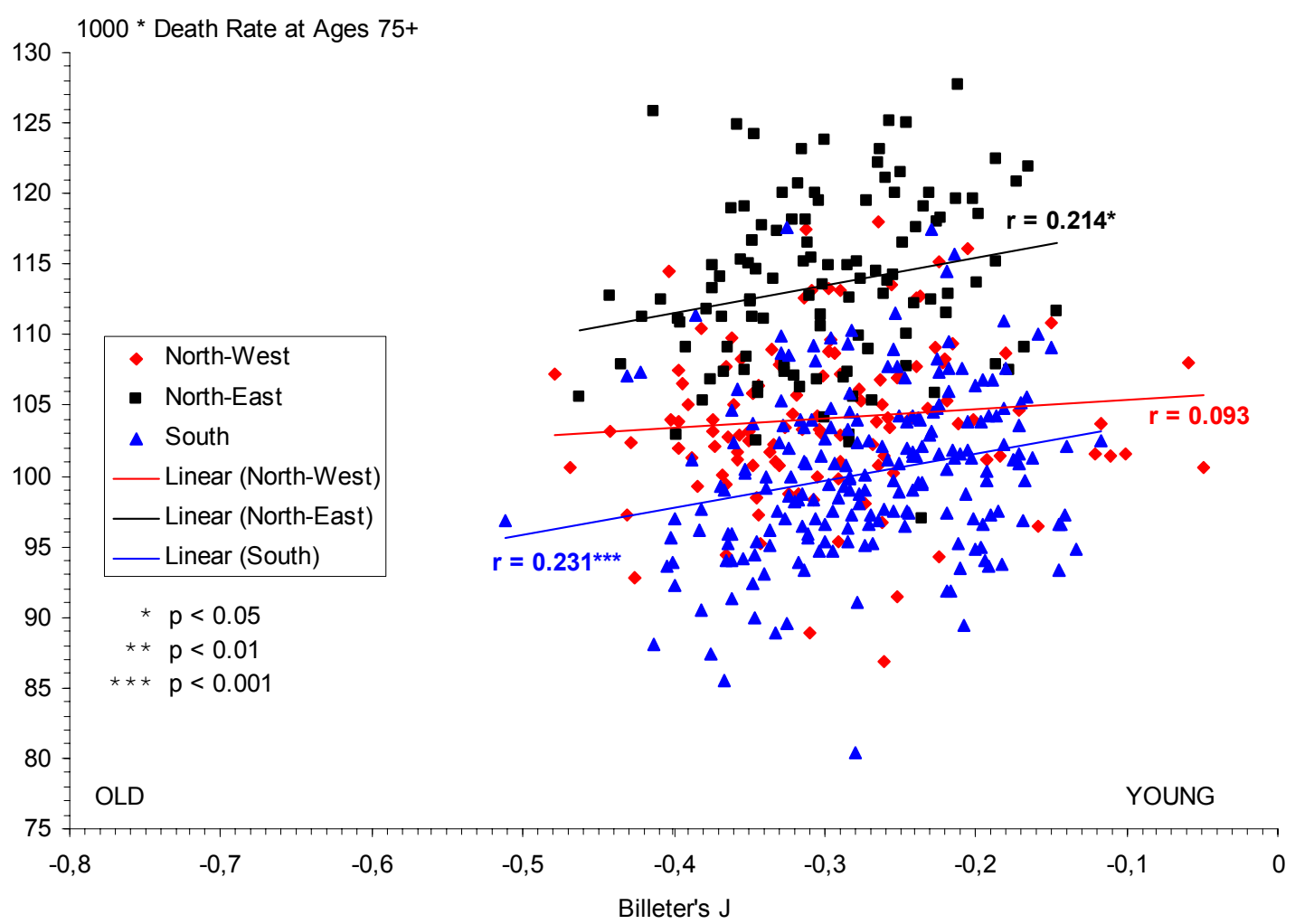

Fig. 15: Relationship between Billeter's J and death rate at ages $75+(* 1000)$ for the 103 Italian districts with Pearson's $r$ and statistical significance, males

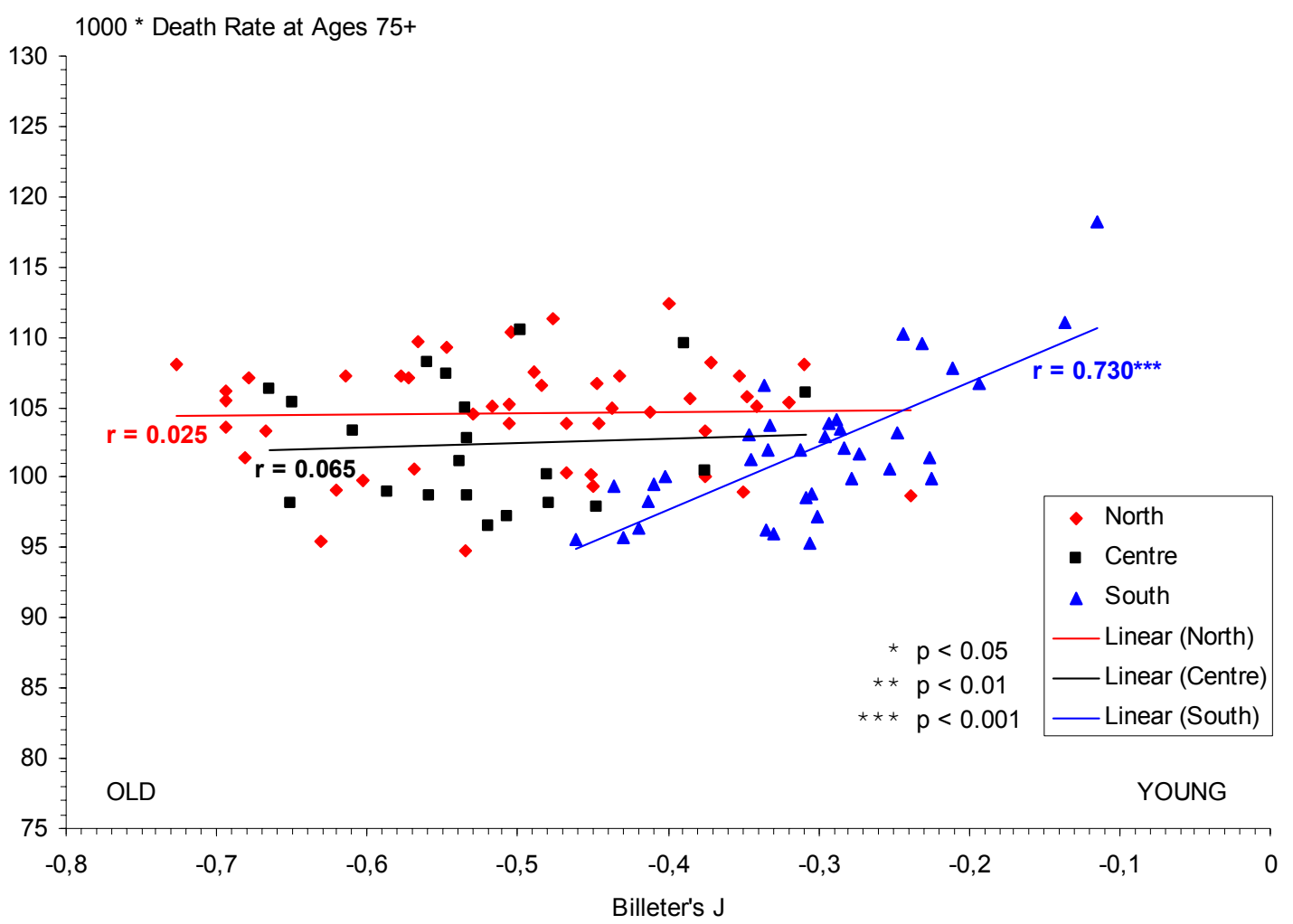


Fig. 16: Relationship between Billeter's J and life expectancy at birth e(0) with Pearson's $r$ for the 440 German districts and statistical significance, females

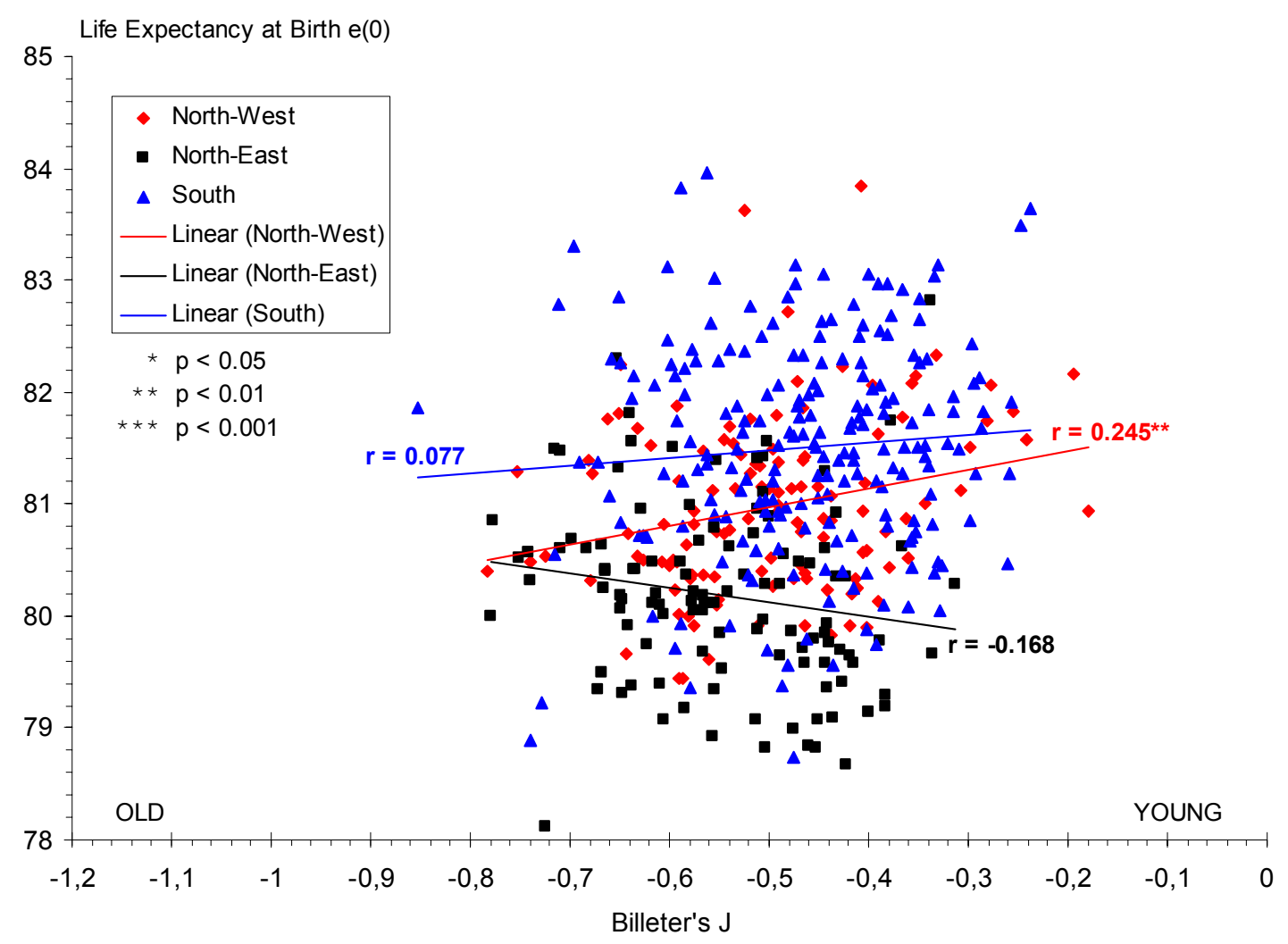

Fig. 17: Relationship between Billeter's J and life expectancy at birth e(0) for the 103 Italian districts with Pearson's $r$ and statistical significance, females

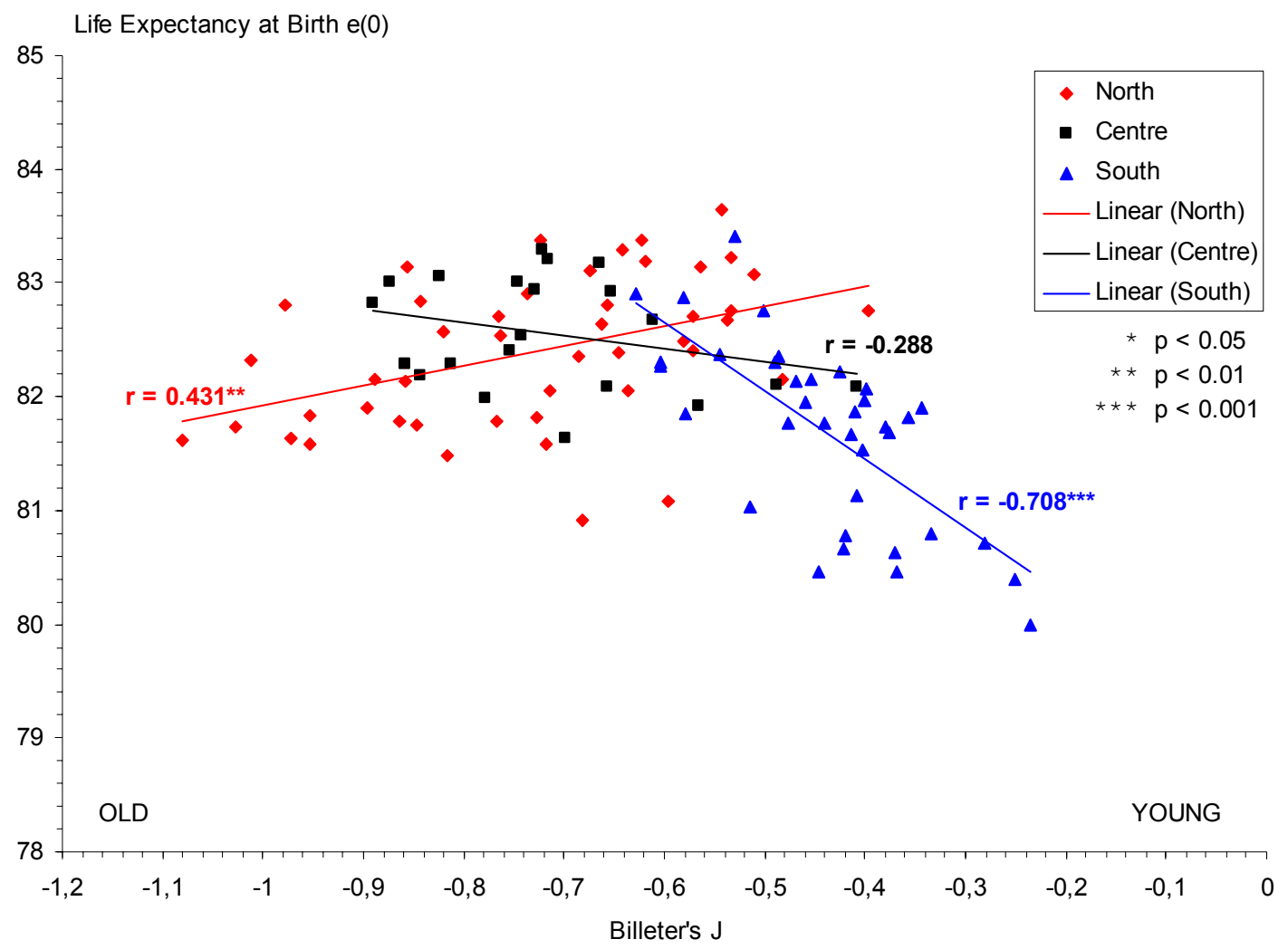


Fig. 18: Relationship between Billeter's J and probability of dying at ages $15-40{ }_{25} \mathrm{q}_{15}$ for the 440 German districts with Pearson's $r$ and statistical significance, females

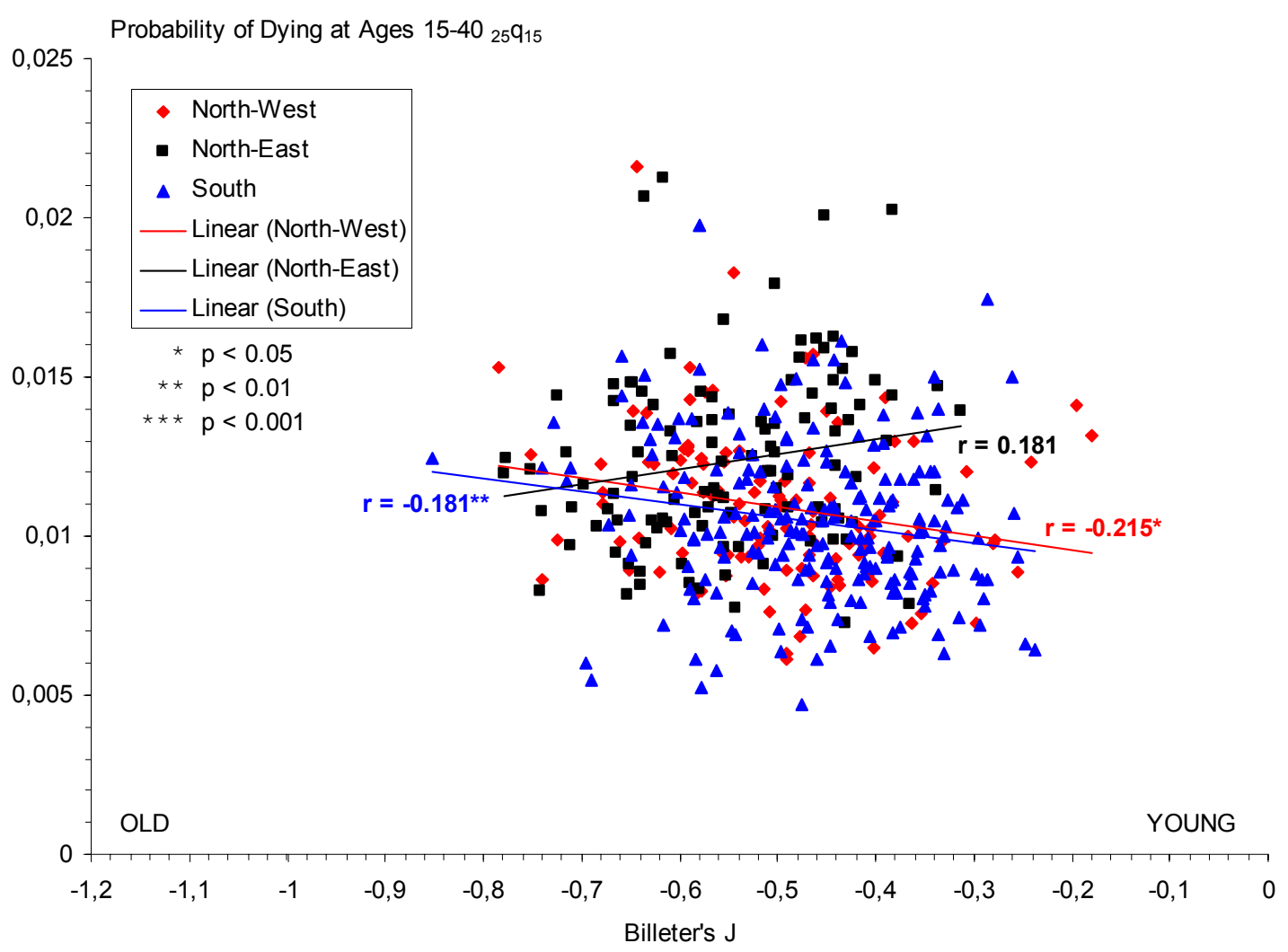

Fig. 19: Relationship between Billeter's J and probability of dying at ages $15-40_{25} \mathrm{q}_{15}$ for the 103 Italian districts with Pearson's $r$ and statistical significance, females

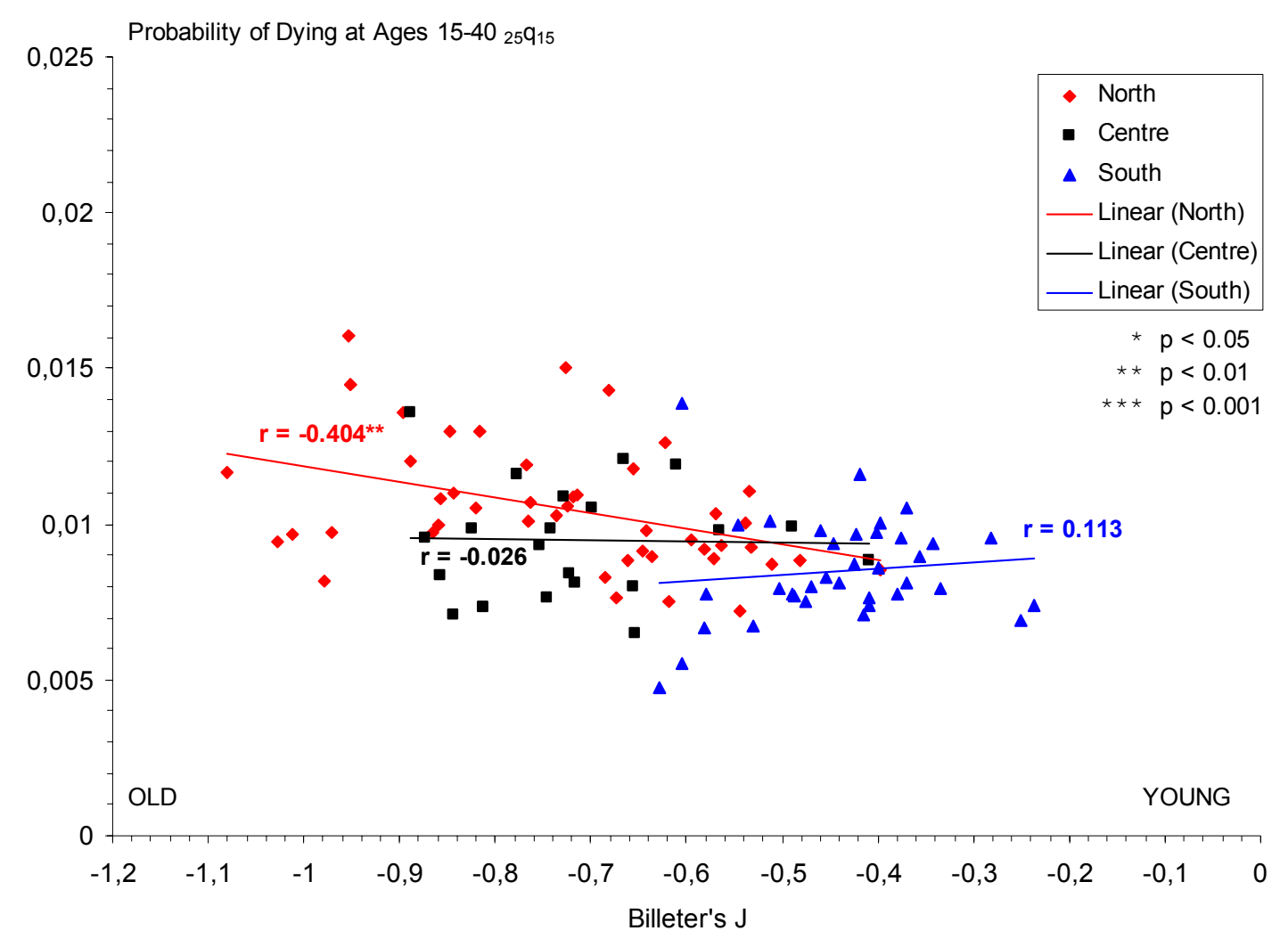


Fig. 20: Relationship between Billeter's $J$ and probability of dying at ages 50 and $75{ }_{25} \mathrm{q}_{50}$ for the 440 German districts with Pearson's $r$ and statistical significance, females

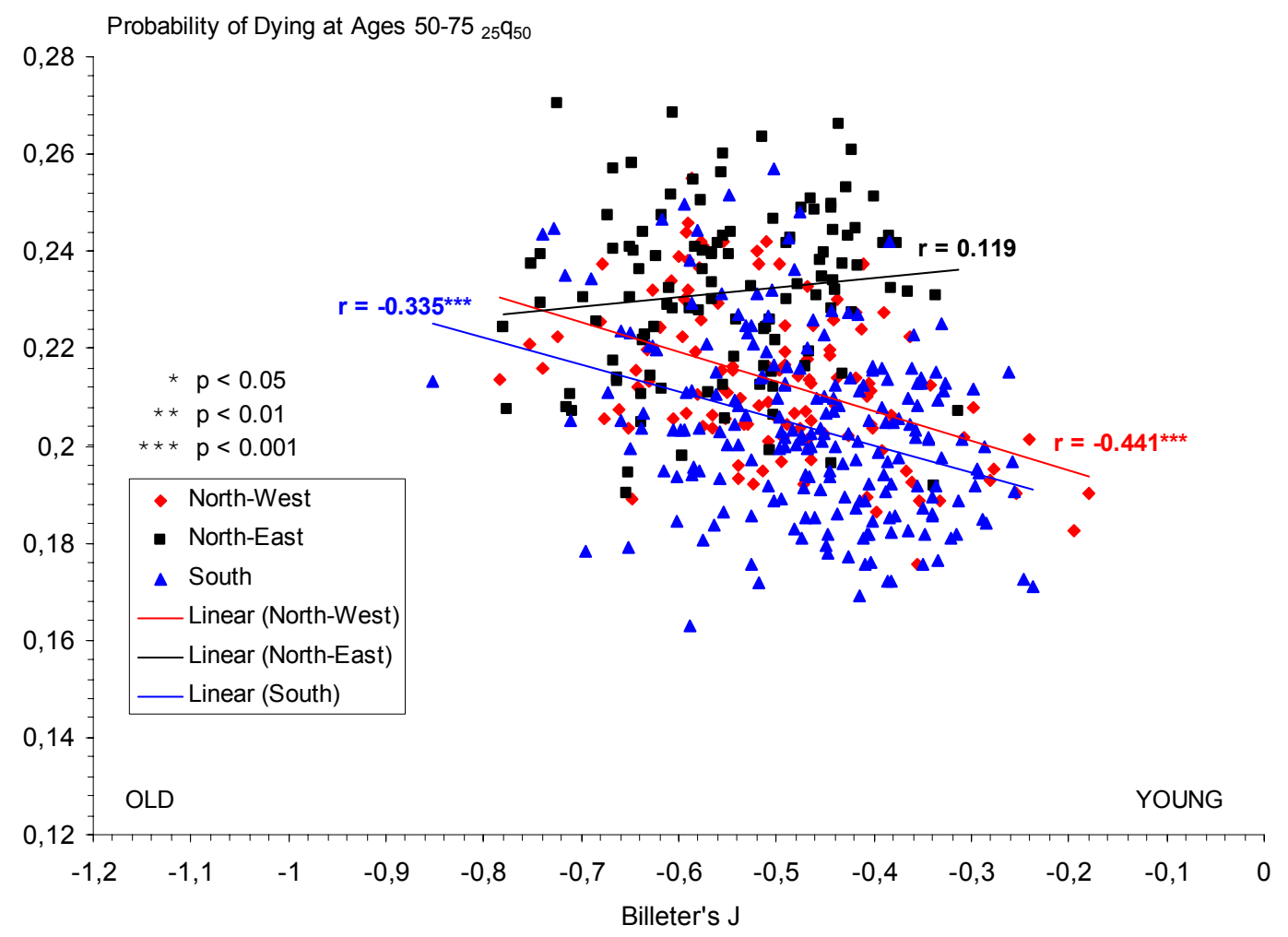

Fig. 21: Relationship between Billeter's J and probability of dying at ages $50-75{ }_{25} \mathrm{q}_{50}$ for the 103 Italian districts with Pearson's $r$ and statistical significance, females

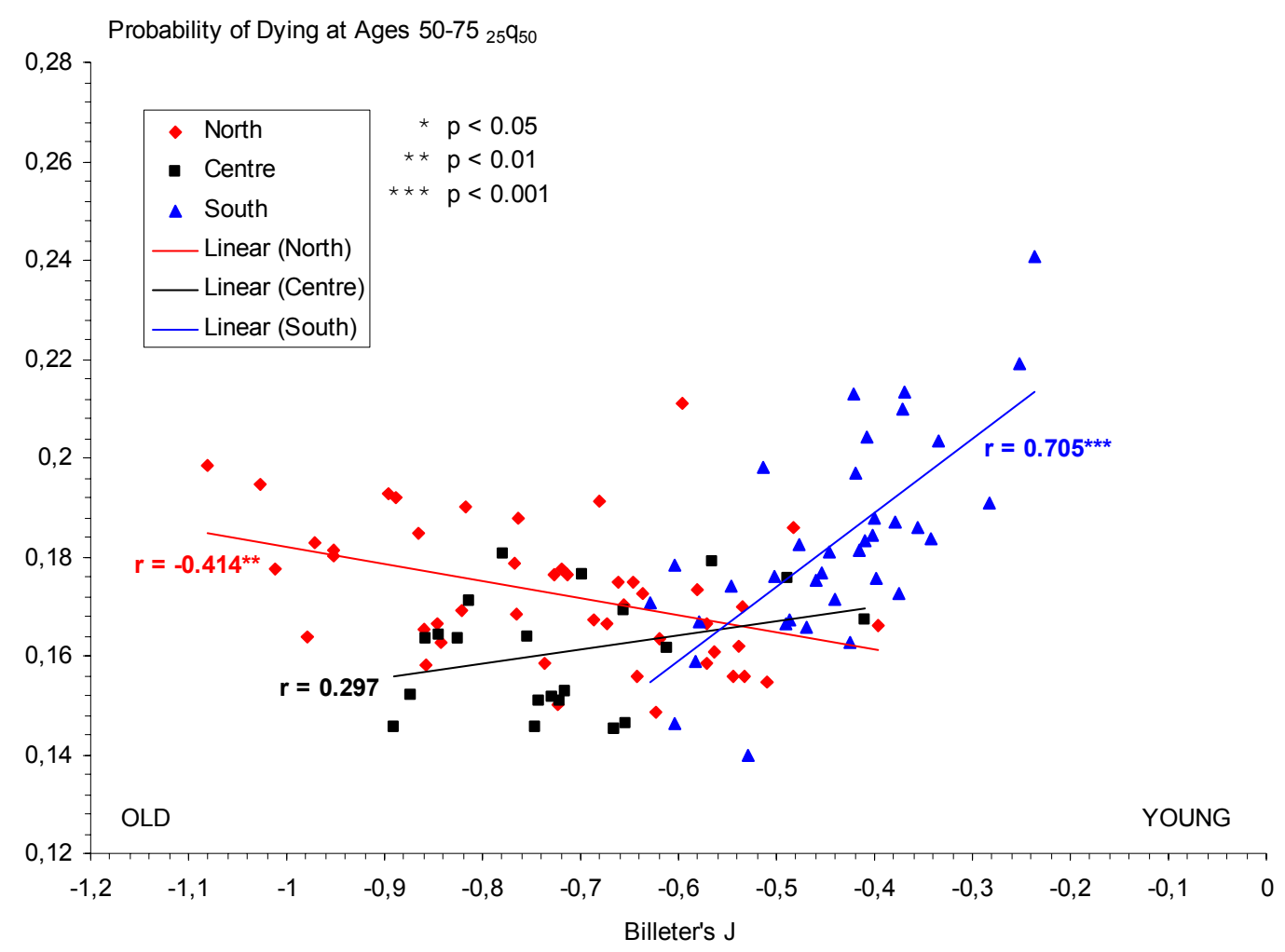


Fig. 22: Relationship between Billeter's J and death rate at ages $75+(* 1000)$ for the 440 German districts with Pearson's $r$ and statistical significance, females

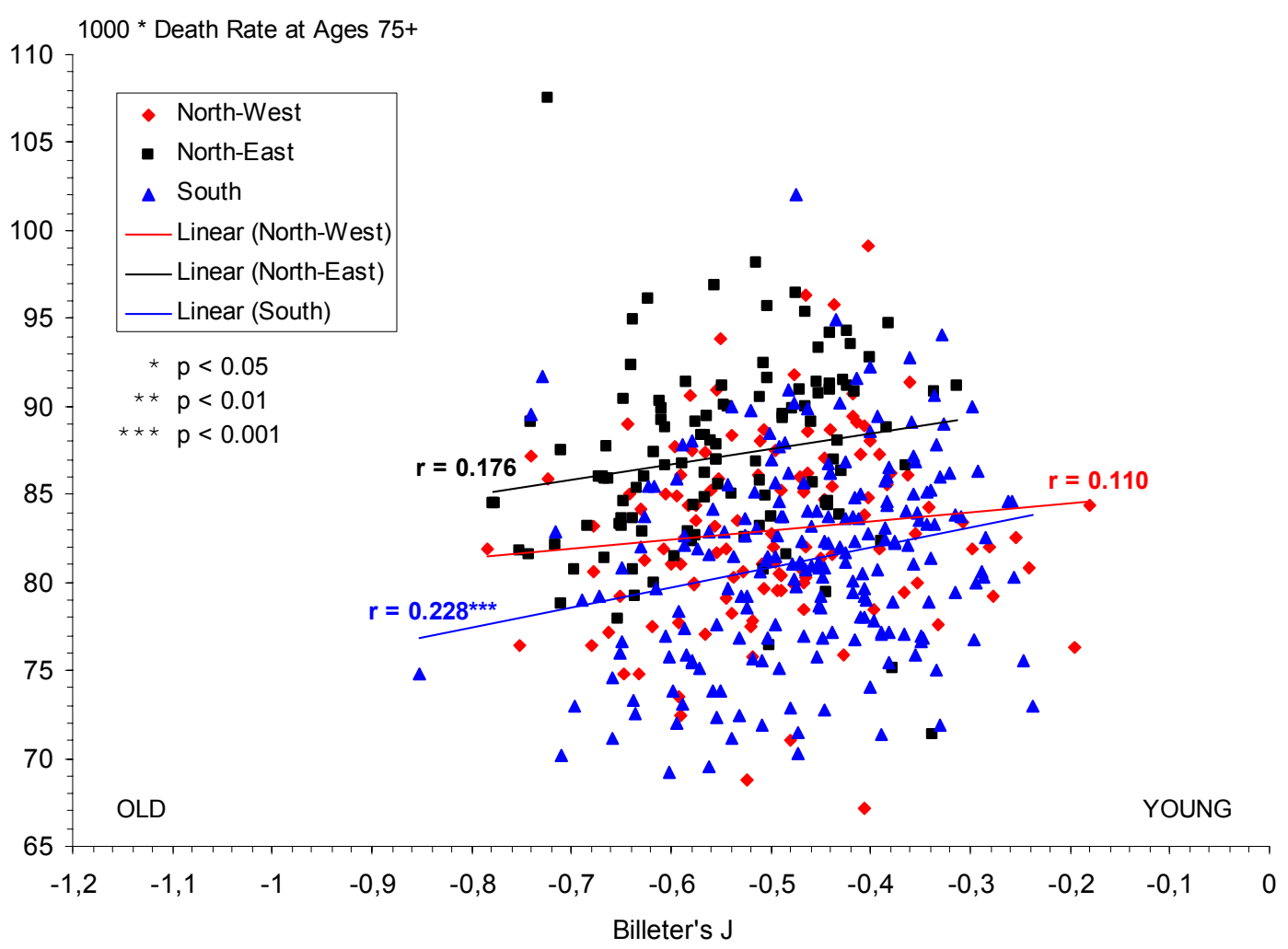

Fig. 23: Relationship between Billeter's J and death rate at ages $75+(* 1000)$ for the 103 Italian districts with Pearson's $r$ and statistical significance, females

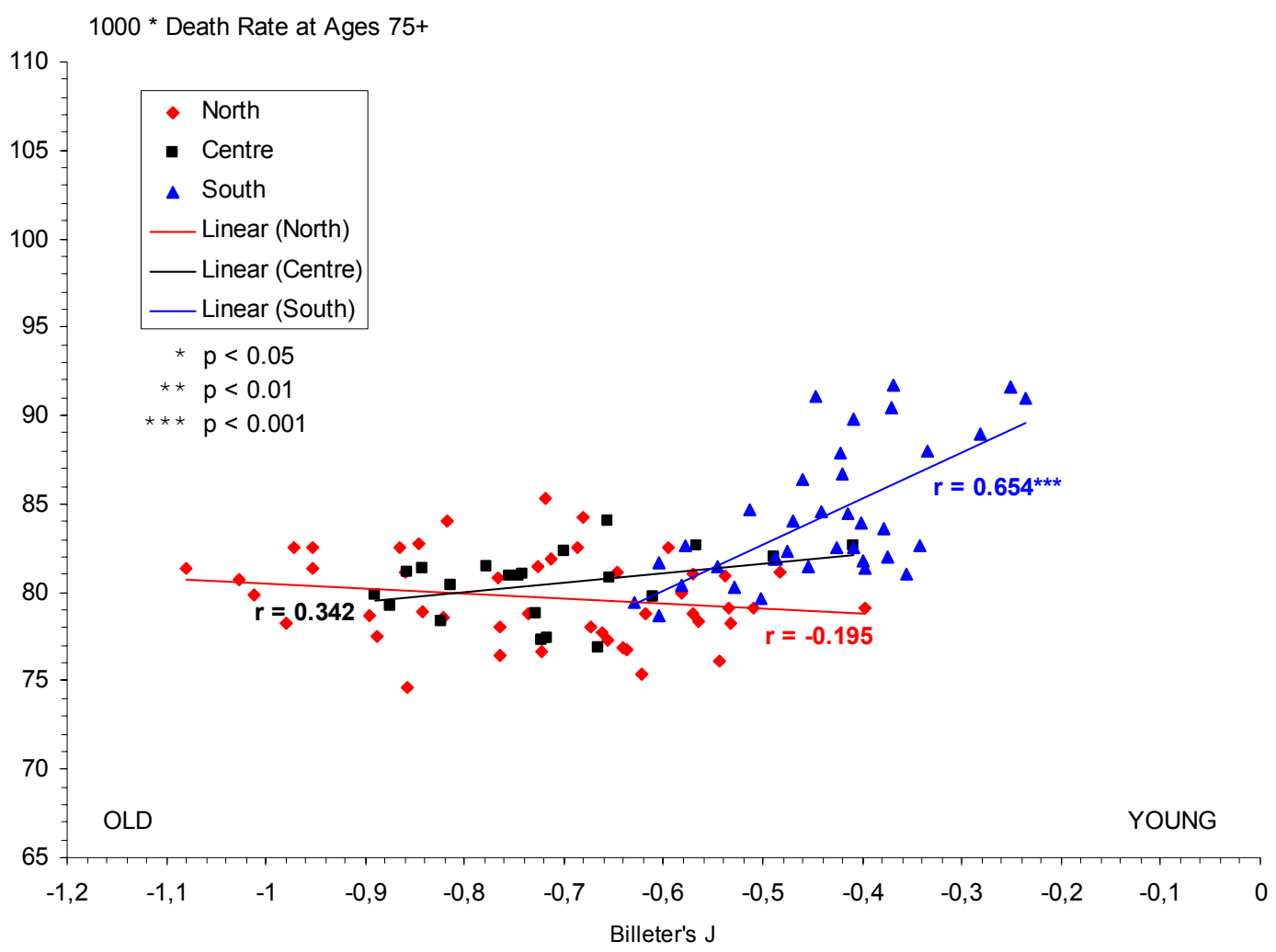


Tab. 1: Number of districts and variance of parameter values for life expectancy at birth and Billeter's J for German regions (“Bundesländer”)

\begin{tabular}{|c|c|c|c|c|c|c|c|c|c|c|c|c|c|}
\hline & \multirow[b]{3}{*}{ Districts } & \multicolumn{6}{|c|}{ Men } & \multicolumn{6}{|c|}{ Women } \\
\hline & & \multicolumn{3}{|c|}{ Life Expectancy e(0) } & \multicolumn{3}{|c|}{ Billeter's J } & \multicolumn{3}{|c|}{ Life Expectancy e(0) } & \multicolumn{3}{|c|}{ Billeter's J } \\
\hline & & Min & $\operatorname{Max}$ & Span & Min & $\operatorname{Max}$ & Span & Min & Max & Span & Min & Max & Span \\
\hline NORTH-WEST & 119 & 73.03 & 77.36 & 4.33 & -0.48 & -0.05 & 0.43 & 79.44 & 83.84 & 4.40 & -0.78 & -0.18 & 0.60 \\
\hline Bremen & 2 & 73.03 & 74.18 & 1.15 & -0.38 & -0.37 & 0.01 & 81.21 & 81.68 & 0.47 & -0.63 & -0.59 & 0.04 \\
\hline Hamburg & 1 & 74.97 & 74.97 & - & -0.34 & -0.34 & - & 80.94 & 80.94 & - & -0.58 & -0.58 & - \\
\hline Niedersachsen & 47 & 73.47 & 76.54 & 3.07 & -0.48 & -0.05 & 0.43 & 79.44 & 83.63 & 4.19 & -0.78 & -0.18 & 0.60 \\
\hline Nordrhein-Westfalen & 54 & 72.43 & 77.36 & 4.93 & -0.47 & -0.11 & 0.36 & 79.44 & 83.84 & 4.40 & -0.72 & -0.25 & 0.47 \\
\hline Schleswig-Holstein & 15 & 73.46 & 75.94 & 2.48 & -0.43 & -0.28 & 0.15 & 79.61 & 81.81 & 2.20 & -0.68 & -0.44 & 0.24 \\
\hline NORTH-EAST & 113 & 69.89 & 75.56 & 5.67 & -0.46 & -0.15 & 0.31 & 78.11 & 82.81 & 4.70 & -0.78 & -0.31 & 0.47 \\
\hline Berlin & 1 & 73.96 & 73.96 & - & -0.28 & -0.28 & - & 79.65 & 79.65 & - & -0.49 & -0.49 & - \\
\hline Brandenburg & 18 & 70.93 & 74.93 & 4.00 & -0.37 & -0.20 & 0.17 & 79.29 & 81.42 & 2.13 & -0.65 & -0.38 & 0.27 \\
\hline Mecklenburg-Vorpommern & 18 & 69.89 & 73.78 & 3.89 & -0.35 & -0.15 & 0.20 & 78.85 & 82.81 & 3.96 & -0.64 & -0.31 & 0.33 \\
\hline Sachsen & 29 & 71.48 & 75.56 & 4.08 & -0.46 & -0.24 & 0.22 & 79.38 & 82.30 & 2.92 & -0.78 & -0.44 & 0.34 \\
\hline Sachsen-Anhalt & 24 & 71.52 & 73.88 & 2.36 & -0.44 & -0.21 & 0.23 & 78.67 & 81.48 & 2.81 & -0.71 & -0.42 & 0.29 \\
\hline Thüringen & 23 & 71.67 & 75.48 & 3.81 & -0.41 & -0.17 & 0.24 & 78.11 & 81.57 & 3.46 & -0.72 & -0.37 & 0.35 \\
\hline SOUTH & 208 & 72.48 & 78.42 & 5.94 & -0.51 & -0.12 & 0.39 & 78.73 & 83.96 & 5.23 & -0.85 & -0.24 & 0.61 \\
\hline Baden-Württemberg & 44 & 74.28 & 77.17 & 2.89 & -0.51 & -0.12 & 0.39 & 79.88 & 83.49 & 3.61 & -0.85 & -0.25 & 0.60 \\
\hline Bayern & 96 & 72.48 & 78.42 & 5.94 & -0.43 & -0.14 & 0.29 & 79.23 & 83.96 & 4.73 & -0.73 & -0.24 & 0.49 \\
\hline Hessen & 26 & 73.41 & 77.62 & 4.21 & -0.39 & -0.21 & 0.18 & 79.57 & 83.12 & 3.55 & -0.63 & -0.36 & 0.27 \\
\hline Rheinland-Pfalz & 36 & 73.23 & 76.08 & 2.85 & -0.42 & -0.19 & 0.23 & 78.73 & 82.32 & 3.59 & -0.74 & -0.30 & 0.44 \\
\hline Saarland & 6 & 73.44 & 75.22 & 1.78 & -0.36 & -0.28 & 0.08 & 79.36 & 81.44 & 2.08 & -0.59 & -0.49 & 0.10 \\
\hline GERMANY & 440 & 69.89 & 78.42 & 8.53 & -0.51 & -0.05 & 0.46 & 78.11 & 83.96 & 5.85 & -0.85 & -0.18 & 0.67 \\
\hline
\end{tabular}


Tab. 2: Number of districts and variance of parameter values for life expectancy at birth and Billeter's J for Italian regions (“Regioni”)

\begin{tabular}{|c|c|c|c|c|c|c|c|c|c|c|c|c|c|}
\hline & \multirow[b]{3}{*}{ Districts } & \multicolumn{6}{|c|}{ Men } & \multicolumn{6}{|c|}{ Women } \\
\hline & & \multicolumn{3}{|c|}{ Life Expectancy e $(0)$} & \multicolumn{3}{|c|}{ Billeter's J } & \multicolumn{3}{|c|}{ Life Expectancy e(0) } & \multicolumn{3}{|c|}{ Billeter's J } \\
\hline & & Min & $\operatorname{Max}$ & Span & Min & $\operatorname{Max}$ & Span & Min & $\operatorname{Max}$ & Span & Min & $\operatorname{Max}$ & Span \\
\hline NORTH & 46 & 73.75 & 77.70 & 3.95 & -0.73 & -0.24 & 0.49 & 80.91 & 83.64 & 2.73 & -1.08 & -0.40 & 0.68 \\
\hline Emilia Romagna & 9 & 75.00 & 77.70 & 2.70 & -0.68 & -0.45 & 0.23 & 81.59 & 83.38 & 1.79 & -0.95 & -0.62 & 0.33 \\
\hline Friuli - Venezia Giulia & 4 & 74.84 & 76.00 & 1.16 & -0.69 & -0.44 & 0.25 & 81.62 & 82.80 & 1.18 & -1.08 & -0.66 & 0.42 \\
\hline Liguria & 4 & 75.46 & 76.25 & 0.79 & -0.73 & -0.67 & 0.06 & 81.74 & 82.81 & 1.07 & -1.03 & -0.95 & 0.08 \\
\hline Lombardia & 11 & 73.75 & 76.11 & 2.36 & -0.55 & -0.31 & 0.24 & 81.08 & 83.19 & 2.11 & -0.74 & -0.48 & 0.26 \\
\hline Piemonte & 8 & 74.62 & 76.13 & 1.51 & -0.69 & -0.45 & 0.24 & 80.91 & 82.35 & 1.44 & -0.97 & -0.68 & 0.29 \\
\hline Trentino - Alto Adige & 2 & 76.05 & 76.44 & 0.39 & -0.35 & -0.24 & 0.11 & 82.76 & 83.64 & 0.88 & -0.54 & -0.40 & 0.14 \\
\hline Valle D'Aosta & 1 & 74.17 & 74.17 & - & -0.45 & -0.45 & - & 82.06 & 82.06 & - & -0.64 & -0.64 & - \\
\hline Veneto & 7 & 74.88 & 76.56 & 1.68 & -0.51 & -0.32 & 0.19 & 81.82 & 83.23 & 1.41 & -0.76 & -0.51 & 0.25 \\
\hline CENTRE & 21 & 74.80 & 77.74 & 2.94 & -0.66 & -0.31 & 0.35 & 81.64 & 83.29 & 1.65 & -0.89 & -0.41 & 0.48 \\
\hline Lazio & 5 & 75.56 & 76.02 & 0.46 & -0.53 & -0.31 & 0.22 & 81.64 & 82.10 & 0.46 & -0.70 & -0.41 & 0.29 \\
\hline Marche & 4 & 76.59 & 77.62 & 1.03 & -0.52 & -0.48 & 0.04 & 82.93 & 83.29 & 0.36 & -0.72 & -0.65 & 0.07 \\
\hline Toscana & 10 & 74.80 & 77.74 & 2.94 & -0.66 & -0.45 & 0.21 & 81.98 & 83.06 & 1.08 & -0.89 & -0.61 & 0.28 \\
\hline Umbria & 2 & 76.36 & 77.20 & 0.84 & -0.65 & -0.53 & 0.12 & 82.29 & 82.94 & 0.65 & -0.86 & -0.73 & 0.13 \\
\hline SOUTH & 36 & 73.79 & 77.19 & 3.40 & -0.46 & -0.11 & 0.35 & 79.99 & 83.41 & 3.42 & -0.63 & -0.28 & 0.35 \\
\hline Abruzzo & 4 & 76.19 & 77.19 & 1.00 & -0.46 & -0.40 & 0.06 & 82.90 & 83.41 & 0.51 & -0.63 & -0.53 & 0.10 \\
\hline Basilicata & 2 & 76.81 & 77.03 & 0.22 & -0.34 & -0.30 & 0.04 & 81.66 & 81.76 & 0.10 & -0.48 & -0.41 & 0.07 \\
\hline Calabria & 5 & 75.53 & 77.19 & 1.66 & -0.30 & -0.19 & 0.11 & 80.72 & 82.07 & 1.35 & -0.41 & -0.28 & 0.13 \\
\hline Campania & 5 & 73.79 & 76.94 & 3.15 & -0.35 & -0.11 & 0.24 & 79.99 & 82.76 & 2.77 & -0.50 & -0.24 & 0.26 \\
\hline Molise & 2 & 76.06 & 76.72 & 0.66 & -0.43 & -0.42 & 0.01 & 81.86 & 82.27 & 0.41 & -0.60 & -0.58 & 0.02 \\
\hline Puglia & 5 & 75.80 & 76.94 & 1.14 & -0.33 & -0.22 & 0.11 & 81.54 & 82.30 & 0.76 & -0.49 & -0.34 & 0.15 \\
\hline Sardegna & 4 & 75.35 & 76.29 & 0.94 & -0.41 & -0.31 & 0.10 & 81.95 & 82.37 & 0.42 & -0.55 & -0.43 & 0.12 \\
\hline Sicilia & 9 & 74.69 & 76.13 & 1.44 & -0.34 & -0.21 & 0.13 & 80.46 & 82.14 & 1.68 & -0.51 & -0.33 & 0.18 \\
\hline ITALY & 103 & 73.75 & 77.74 & 3.99 & -0.73 & -0.11 & 0.62 & 79.99 & 83.64 & 3.65 & -1.08 & -0.28 & 0.80 \\
\hline
\end{tabular}


Tab. 3: Pearson's $r$ with statistical significance for the relationship between Billeter's J and the used mortality indicators for Germany and Italy

\begin{tabular}{|c|c|c|c|c|c|c|c|}
\hline \multirow[b]{2}{*}{ Germany, Mer } & \multicolumn{2}{|l|}{$e_{0}$} & ${ }_{25} q_{15}$ & \multicolumn{2}{|l|}{${ }_{25} q_{50}$} & \multicolumn{2}{|l|}{$\mathrm{M}_{75+}$} \\
\hline & & & & & & & \\
\hline North-West & 0.238 & $* *$ & -0.057 & -0.292 & $* *$ & 0.093 & \\
\hline North-East & -0.325 & $* * *$ & $0.256 * *$ & 0.247 & $* *$ & 0.214 & * \\
\hline South & 0.105 & & 0.006 & -0.136 & * & 0.231 & $* * *$ \\
\hline \multicolumn{8}{|c|}{ Germany, Women } \\
\hline North-West & 0.245 & ** & $-0.215 *$ & -0.441 & $* * *$ & 0.110 & \\
\hline North-East & -0.168 & & 0.181 & 0.119 & & 0.176 & \\
\hline South & 0.077 & & $-0.181 * *$ & -0.335 & $* * *$ & 0.228 & $* * *$ \\
\hline \multicolumn{8}{|l|}{ Italy, Men } \\
\hline North & 0.029 & & -0.238 & 0.130 & & 0.025 & \\
\hline Centre & -0.130 & & 0.164 & 0.064 & & 0.065 & \\
\hline South & -0.552 & $* * *$ & 0.078 & 0.464 & ** & 0.730 & $* * *$ \\
\hline \multicolumn{8}{|l|}{ Italy, Women } \\
\hline North & 0.431 & $* * *$ & $-0.404^{* *}$ & -0.414 & $* *$ & -0.195 & \\
\hline Centre & -0.288 & & -0.026 & 0.297 & & 0.342 & \\
\hline South & -0.708 & $* * *$ & 0.113 & 0.705 & $* * *$ & 0.654 & $* * *$ \\
\hline
\end{tabular}

* $p<0.05$

** $p<0.01$

*** $p<0.001$ 